\title{
Omnibus Omnia: The Reception of Socrates in Ante-Nicene Christian Literature
}

\author{
Juraj Franek
}

\begin{abstract}
The figure of Socrates features prominently in the works of earliest Christian authors and their attempts to negotiate a viable relation between pagan intellectual tradition and the exigencies of a newly founded religion. The analysis of all relevant ante-Nicene Greek and Latin texts shows that early Christian writers reconstruct "Socrates" with a striking degree of interpretative freedom. Although it is impossible to establish a unified perspective on Socrates in these texts - let alone a positive one, as many previous commentators thought -, the interpretations of the Athenian sage are not entirely haphazard. I argue that they are heavily constrained by apologetic aims of early Christian authors and closely connected to epistemic justification of faith by means of miracles, superior moral behaviour, divine inspiration and prophecy, and, finally, the emphasis that is placed on the limitations of human, all too human, wisdom.
\end{abstract}

\section{Key words}

Socrates; reception; early Christian literature; epistemic justification; apologetics; miracles; morality; divine inspiration

Gegen den Positivismus, welcher bei dem Phänomen stehen bleibt „es giebt nur Thatsachen “,würde ich sagen: nein, gerade Thatsachen giebt es nicht, nur Interpretationen. (Nietzsche) ${ }^{1}$

Socrates, an unforgettable and larger-than-life character that animates the majority of Platonic dialogues, some of Xenophon's writings and a single comedy by Aristophanes, is featured prominently in the writings of early Christian authors, while his reception is not limited to literary works, but also makes an appearance in several artistic creations of the period. ${ }^{2}$ In spite of a considerable number of studies on the subject, of which

1 Nietzsche (1999: Vol. XII, p. 315).

2 Hanfmann (1951) analyzed the mosaic of Socrates and his followers, found in Apamea in 1938, in terms of its later influence on early Christian iconography and concludes that "during the third century, some Christian artist, whose views on Socrates may have resembled those of Justin, adopted the composition portraying Socrates and his disciples and thus established a type for the portrayal of Christ as the Teacher of Truth, a type that was to evolve into some of the most majestic compositions of Early Christian art" 
especially the recent ones rightly emphasize the essential ambiguity of the reception of Socrates in early Christian literature, ${ }^{3}$ to my best knowledge, no attempt has been made to identify the underlying motivations behind the recreation of the Socratic figure by Christian authors in the first three centuries CE. I will argue that the hermeneutical key that opens variegated interpretations of the Athenian sage and embeds them in a coherent, unified system, is provided by an important distinction between the type of argumentation common in Greek and Roman philosophy and between the type of epistemic justification that is consistently used in early Christian literature.

I will presuppose that the guiding principle of Greek and Roman philosophy may be summarized positively as a virtually unquestionable reliance on ratiocination and negatively as a resolute refusal to accept any ad hominem arguments based on authority in the philosophical discourse. Put simply by Cicero, "in discussion it is not so much authorities as determining reasons that should be looked for". ${ }^{4}$ Notwithstanding some complications arising from the peculiar nature of the Greek term $\alpha \lambda \eta \dot{\theta} \theta \iota \alpha$ and accommodating for a slight anachronism, ${ }^{5}$ Pilate's infamous question (What is truth? $)^{6}$ would be answered by pagan philosophers by an emphatic statement that truth is, by and large, a property of a proposition and a truth value of a proposition is entirely independent of the specific character, abilities or conduct of the speaker (unless the proposition chances to describe precisely his or her character, abilities, or conduct, of course). ${ }^{7}$

Early Christian authors develop a very different strand of argumentative strategy to justify their beliefs (a detailed study on this subject is forthcoming). Caught in a tug of war over Tertullian's alleged fideism, Anthony Guerra introduces the concept of "warrants of Christian faith", which are five: (1) scripture; (2) reason; (3) superior moral

(op. cit., p. 217). Prolović (2011) highlights iconographic parallelism between the portrayal of Socrates and John the Apostle which "developed in the first centuries of Christianity" (op. cit., p. 18). Zanker (1995) provides a detailed discussion of the representation of the intellectual in classical antiquity, focusing also on parallels with the early Christian portrayal of Jesus (op. cit., pp. 272-287). Lapatin (2006) offers a comprehensive iconographical history of Socrates from the earliest instances to the present day, without delineating any connections with early Christian art.

3 In the past 20 years, several studies on the topic have been published. Ritter (1998), despite the title, does not deal with the reception of Socrates in early Christian literature in any detail. Döring (1999), Frede (2006) and Edwards (2007) are general studies with purely descriptive aims that, curiously enough, make practically no use of the voluminous secondary literature on the subject. Two recent studies by the French scholar Guillaume Bady (Bady 2014; 2015), while valuable in their own right, focus more on the larger philosophical and theological issues connected with Socrates' reception in early Christianity and his discussion extends far into the patristic literature.

4 Cicero, De natura deorum 1.5.10: non enim tam auctoritatis in disputando quam rationis momenta quaerenda sunt. Socrates himself would undoubtedly concur. In Plato's Crito (46b4-6), he admits that he finds bind-

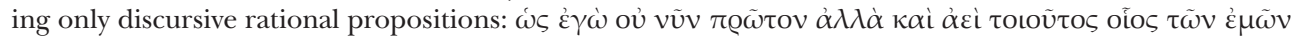

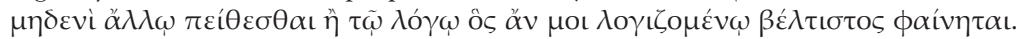

5 On the difference between the Greek notion of $\alpha \lambda \eta \dot{\theta \varepsilon \iota \alpha}$ and Western "rational" concept of "truth" see Detienne (1967); Heidegger (2006) and esp. Heidegger (1969: pp. 61-80).

6 John 18, 38.

7 As a result of a comparison of Greek and Roman philosophical method with the argumentation of early Christian authors, Barnes (1997: p. 207) comes to a conclusion that there is not a single Greek philosophical or scientific text in which its basic principles would be defended by an appeal to authority. 
behaviour; (4) spiritual testimony; and (5) tradition. ${ }^{8}$ It is not clear what Guerra understands by "reason"; it is certainly true that some of the apologists do appeal to ratiocination that is unaided by revelation, yet - more importantly - they never fail to emphasize that this knowledge is partial and provisional at best. ${ }^{9}$ Conspicuously missing from Guerra's list are miracles, which are clearly used by virtually all earliest Christian authors as a means of epistemic justification of their beliefs. Modifying slightly Guerra's list, I suggest that the early Christian warrants of faith consist primarily, but not exclusively, in (1) miracles; (2) superior moral behaviour; and (3) divine inspiration and prophecy. If this holds, it follows that epistemic justification in early Christianity is markedly different from epistemic justification in Greek and Roman philosophy.

While pagan wisdom generally does not allow for ad hominem arguments from authority, the larger part of early Christian apologetics is based precisely on them. The truthmaker of a proposition (especially a proposition concerned with credenda) is the person with whom the proposition originates, and the overall logical structure of epistemic justification may be reduced to a following argument:

(p1) If an individual $x$ possesses a property $P$, then the truth value of a proposition entertained by $x$ is "true", while $P$ is any combination of (1) the ability to work true miracles; (2) superior moral behaviour, usually demonstrated by voluntary suffering for one's beliefs; (3) access to direct divine inspiration and the ability to prophecy.

(p2) Jesus, the Apostles, and some of their followers demonstrated the possession of a property $P$.

(c) Propositions entertained by Jesus, the Apostles and some of their followers are true (by modus ponens from first two premises).

If it is granted that epistemic justification in early Christian literature is heavily dependent on what essentially amounts to ad hominem argument from authority, then it follows as a working hypothesis that all of the variegated recreations of the figure of Socrates will be informed by one single interpretive principle that aims to defend not so much any particular piece of Christian doctrine (this is why there are mutually exclusive assessments of Socrates), but the very model of epistemic justification that makes, in the view of earliest apologists, Christian doctrine credible in the first place. This aim is greatly facilitated by ostentatious indifference to "historical" Socrates and to the unyielding attempts to disentangle Socratic and Platonic elements that make part and parcel of the modern scholarship on the "Socratic problem"; ${ }^{10}$ after all, early Christian writers share this indifference with pagan philosophers of the Hellenistic schools. ${ }^{11}$ For apologists of

8 Guerra (1991: p. 109).

9 See also section (4) of this paper.

10 Good recent short introductions to the Socratic problem are Giannantoni (2001), Dorion (2011), Waterfield (2013) and Stavrou (2013). Historically important is especially Gigon (1947), advocating skepticism, and Vlastos (1991: pp. 45-80), who proposed in his now famous "ten theses" a viable solution for the separation of historical Socrates and Plato. Patzer (1987) and Montuori (1992) collect the most important scholarly contributions.

11 This appears to be a general scholarly consensus; see, for instance, Long (1988: p. 152): "In general, it seems, neither Hellenistic philosophers with an allegiance to Socrates, nor biographers and doxographers, addressed the 'Socratic problem' of modern scholarship."; Erler (2001: p. 209): "Die Frage nach 
the new faith, the Athenian sage is nothing more than a marionette suspended on the strings of their apologetic purposes. The roles he plays are different and changing, but all the movements are guided by a single puppeteer - passionate defence of the epistemic justification based on authority. Accordingly, the study will discuss the role Socrates plays in establishing the arguments based on (1) miracles; (2) superior moral behaviour; (3) divine inspiration and prophecy; and, finally, (4) the role he plays in subordination of human wisdom to divine wisdom, which is the lynchpin of the whole argumentative complex. The corpus of excerpted texts is constituted by the entirety of Greek and Latin Christian literature that can be reasonably dated before the Nicene council and contains explicit or implicit reference to the figure of Socrates. ${ }^{12}$

\section{(1) Argument from miracles, exorcism and Socratic $\delta \alpha \mu$ óvıov}

One does not have to accept in full the enormous role Ramsay MacMullen ascribes to the miracle stories in the spread of Christianity in order to highlight the crucial importance of miracles in early Christian literature. ${ }^{13}$ Foundational texts that later came to be collected under the heading of New Testament clearly portray Jesus as a powerful magic-worker and it has been plausibly argued that, alongside the argument from fulfilled prophecies, discussed in greater detail in section (3), the miracle-working activity of Jesus "was regarded by first- and second-century Christian apologists as the strongest argument for Christianity". ${ }^{14}$ Among these mighty deeds that identify Jesus as a Messiah, exorcisms play a prominent role. ${ }^{15}$ It then goes without saying that the existence of demons has to be assumed and defended in order for the exorcism stories to be credible. While there can be no doubt that a belief in the existence of demons in the Mediterranean socio-cultural environment of the first few centuries of the Common

dem 'historischen' Sokrates wie auch die danach, wie die Xenophonstelle mit anderen Aussagen des Sokrates bei Xenophon und Platon zu vereinen ist, bliebt außer Acht."; Brancacci (2001: p. 169): "La distinction entre le Socrate «historique» et le Socrate «littéraire», qui représente pour les modernes un difficile problème herméneutique et historiographique, est absente de la littérature antique, ou n’y apparaît que de façon épisodique et exceptionnelle."

12 Most of the texts discussed in this study are uncontroversially dated before or around 325 CE. There is much uncertainty about the pseudo-Clementine Homilies; their dating to the third century, as proposed by Strecker (1992: p. 485), may be accepted. Dating of the relevant Acts and Passions of the martyrs by Moss (2010: pp. 177-201) places all discussed works (Martyrdom of Polycarp, Passion of Perpetua and Felicitas, Acts of Apollonius and Martyrdom of Pionius) before $325 \mathrm{CE}$, yet it has to be noted that her late dating of Polycarp (to third century) is not generally accepted. Translations of the New Testament writings follow NRSV, translations of other early Christian texts follow ANF (with occasional minor modifications) or bilingual editions listed in the primary sources.

13 See MacMullen (1981) and MacMullen (1984).

14 Larmer (2011: p. 46).

15 Kollmann (2011: p. 69): “Dämonenaustreibungen gehören zu den am sichersten bezeugten Taten Jesu und stehen im Zentrum seines Wunderwirkens." 
Era was widespread, ${ }^{16}$ well-educated and philosophically minded pagans (such as Celsus, against whom Origen's opus magnum is directed) often voiced objections against what they considered to be a folk superstition. And it is precisely here that Socrates enters into the picture.

It is well attested in Platonic dialogues and the writings of Xenophon that Socrates frequently experienced some form of demonic intervention. ${ }^{17}$ While the intricacies of this experience, as discussed by specialists, cannot be recounted here in any detail ${ }^{18}$ - heated debates are surrounding especially the issues of whether or to what degree Socratic $\delta \alpha$ «óviov contributed to his indictment ${ }^{19}$ and the relationship between his commitment to ratiocination and apparently irrational intrusions of the demonic presence ${ }^{20}$ - for early Christian authors, the very existence of $\delta \alpha$ เóvıov vindicates the existence of demons, and thus legitimizes exorcisms as powerful attestations of Jesus' divine power.

Starting with the simplest instances, Cyprianus notes that "the existence of demons is also acknowledged by poets and Socrates declared that he was instructed and ruled at the will of a demon", ${ }^{21}$ Minucius Felix uses virtually the same argument, ${ }^{22}$ and so does

16 As evidenced, e.g., by numerous findings of curse tablets invoking demons, see Urbanová (2014) for a recent comprehensive overview of the Latin defixiones.

17 I am following Jedrkiewicz (2011: pp. 236-237), who objects to scholarly reification of $\delta \alpha \mu$ óviov and argues that this peculiar Socratic experience (at the very least in Plato's depiction) has nothing whatso-

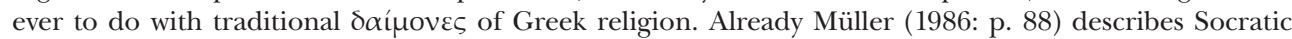

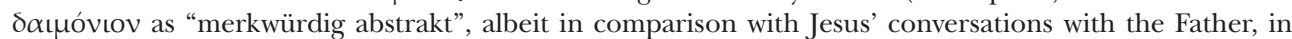
which case it is very abstract indeed.

18 On this topic see especially the edited volume by Destrée \& Smith (2005).

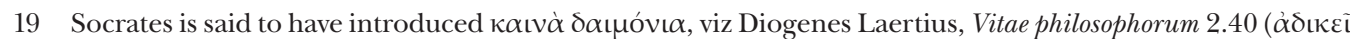

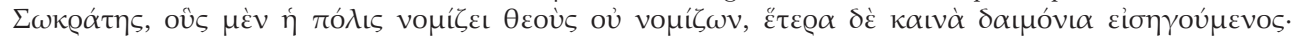

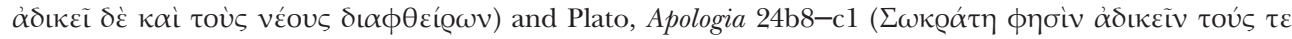

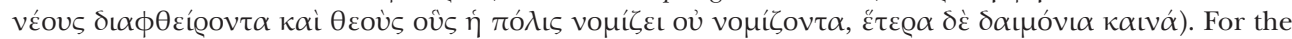
overview of the possible reasons behind the prosecution of Socrates (as well as for relevant primary and selected secondary sources) see Brickhouse \& Smith (2002: esp. pp. 133-243). Vlastos (1991: pp. 162-166) and McPherran (1996: pp. 161-167) argued that the reason behind Socrates' indictment was his moralized conception of the gods; Brickhouse \& Smith (1994: p. 189) deny this and claim that "we should not look to Socrates as a model for the sort of religious criticism or rationalization we now take for granted among philosophers", since "for the most part, Socrates unreflectively accepted and intellectually ignored the jumble of myths that constituted the intellectual component of Greek religion".

20 For a paradigm of Socrates as a rationalist par excellence, see Vlastos (1991: pp. 157-178). Reeve (1989: pp. 62-73) gives due diligence to the religious aspects of Socratic figure but concludes that "an fond his reasons for obeying the oracle are elenchus-based ethical reasons. Socrates is a religious man. But he is not Kierkegaard's Abraham. He is a man of philosophy not of faith.” McPherran (1996: pp. 185-208) provides a good discussion of the topic, defending his own position in discussion with Vlastos' rationalistic thesis and arguing for some epistemological role of extra-rational demonic experience. Brickhouse \& Smith

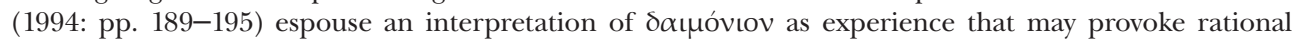
evaluation, but, in itself, is "in no way either product of or qualified by ratiocination" (op. cit., p. 195). Even stronger support for irrational elements in Plato's portrayal of Socrates, verging on mystical experience, has been provided by Bussanich (1999).

21 Cyprianus, Quod idola dii non sint 6: hos et poetae daemonas norunt; Socrates instruit se et regi ad arbitrium daemonis praedicabat.

22 Minucius Felix, Octavius 26.9: eos spiritus daemonas esse poetae sciunt, philosophi disserunt, Socrates novit, qui ad nutum et arbitrium adsidentis sibi daemonis vel declinabat negotia vel petebat. 
Lactantius, who assures his readers that demons are no figments of imagination, since "the philosophers also discuss the subject of these beings. For Plato attempted even to explain their natures in his Symposium; and Socrates said that there was a demon continually about him, who had become attached to him when he was a boy and by whose will and direction his life was guided." ${ }^{23}$ If even the princeps philosophorum is attended by a "demon", it makes little sense on part of the intellectualist pagan elite to attack Christians for being superstitious solely because they posit the existence of these beings.

Tertullianus pursues the same line of thought, however, given his general antipathy to Greek wisdom, he is quick to spell out explicitly the pernicious nature of Socratic

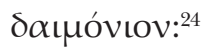

"And we affirm indeed the existence of certain spiritual essences; nor is their name unfamiliar. The philosophers acknowledge there are demons; Socrates himself waiting on a demon's will. Why not? It is said an evil spirit attached itself to him even from his childhood - turning his mind no doubt from what was good." (transl. S. Thelwall)

All these references, drawn mostly from Western apologists, would seem to suggest that the negative interpretation of Socratic $\delta \alpha \iota \mu$ óvıov is the only possible one, yet this conclusion would be unwarranted. Relegating those positive interpretations of the $\delta \alpha \iota \mu$ óvıv connected with divine inspiration and prophecy to section (3) of this paper, it is worthwhile to focus the attention to the interpretation provided by Justin Martyr, ${ }^{25}$ whose very literary output has been claimed to be inspired by Socratic precedents - Plato's and Xenophon's Apologies serve as a model for Apologiae pro Christianis and Dialogus cum Tryphone is created with the method of Socratic discourse in mind. ${ }^{26}$

If for all the Latin apologists discussed thus far the Athenian sage is essentially a man

23 Lactantius, Divinae institutiones 2.14.9: philosophi quoque de his [sc. daemonibus] disserunt. nam Plato etiam naturas eorum in Symposio exprimere conatus est et Socrates esse circa se adsiduum daemona loquebatur, qui puero sibi adhaesisset, cuius nutu et arbitrio sua uita regeretur. Melissoni (1930: p. 155), quite surprisingly, claims that Lactantius' interpretation of the $\delta \alpha$ uóvıov is positive, but the context does not warrant this conclu-

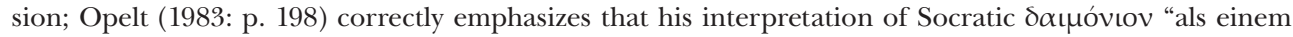
bösen Geist" is the same as that of Cyprianus, Minucius Felix and Tertullian.

24 Tertullianus, Apologeticum 22.1: atque adeo dicimus esse substantias quasdam spiritales. nec novum nomen est: sciunt "daemonas" philosophi, Socrate ipso ad daemonis arbitrium exspectante. quidni? cum ipsi daemonium a pueritia adhaesisse dicatur, dehortatorium plane a bono. See also Tertullian's De anima 1.5 (Socrates facilius diuerso spiritu agebatur, siquidem aiunt daemonium illi a puero adhaessisse, pessimum reuera paedagogum). Explicitly negative connotation of Socratic $\delta \alpha \iota$ óvıov is also found in Minucius Felix, Octavius 38.5: proinde Socrates scurra Atticus viderit, nihil se scire confessus, testimonio licet falacissimi daemonis gloriosus [...].

25 Justin's interpretation of Socrates has been studied in great detail, with no less than four studies devoted exclusively to this topic. Young (1989) highlights Socratic model of philosophy as normative for Justin (as compared with unproductive Middle Platonism), concluding that Justin is "the intellectual child of Plato's Apology, the disciple of the Socrates who is portrayed there" (op. cit., p. 164). Skarsaune (1996) focused on Jewish influences in Justin's recreation of the philosopher and comes to a conclusion that Justin's portrait of Socrates "is not only 'christianized', but also strikingly Jewish" (op. cit., p. 591). Fédou (1998) and Rivas (2003) provide a commented discussion of all Socratic loci in Justin's works, without advancing any peculiar interpretation.

26 Fédou (1998: pp. 52-53); Stegemann (1999: p. 83). 
possessed by a demon, for Justin, Socrates is an exorcist of sorts. In his First Apology, Justin discusses the question of why good people are persecuted and offers a simple answer - it is the work of demons. Peoples before the first advent of Christ did not recognize them as such, however, and that is the reason why they proclaimed them gods and worshipped them. Following this general introduction, an interesting parallel between Socrates and Christians is developed: ${ }^{27}$

\begin{abstract}
"And when Socrates endeavoured, by true reason and examination, to bring these things to light, and deliver men from the demons, then the demons themselves, by means of men who rejoiced in iniquity, compassed his death, as an atheist and a profane person, on the charge that he was introducing new divinities; and in our case they display a similar activity." (transl.

M. Dods \& G. Reith)
\end{abstract}

The parallels between the current situation of Christians and Socrates are unmistakable - just like Christians, Socrates fought against demons; just like Christians, he suffered unjust indictment and death under identical charges (atheism). For Justin, it seems, not only is Socrates not under the influence of an evil demon, quite to the contrary, he is seen as an exorcist of sorts, ${ }^{28}$ cleansing Athens from demonic infestation. In his Second Apology, Justin picks up the theme once more and argues that Socrates "cast out from the state both Homer and the rest of the poets, and taught men to reject the wicked demons and those who did the things which the poets related; and he exhorted them to become acquainted with the God who was to them unknown, by means of the investigation of reason, saying, 'it is neither easy to find the Father and Maker of all, nor, having found Him, is it safe to declare Him to all'." ${ }^{29}$

This important section contains multiple intertextual allusions: Some scholars have plausibly argued that the "unknown God" Socrates announced may well be referenced by the "unknown God" that Paul the Apostle preached at the Areopagus in Athens; $;^{30}$

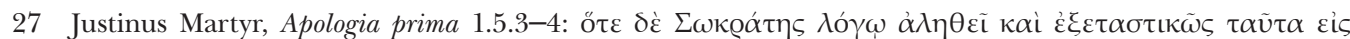

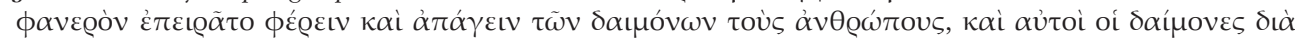

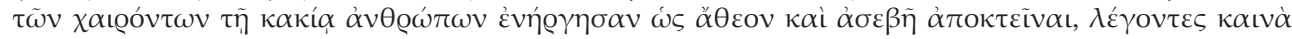

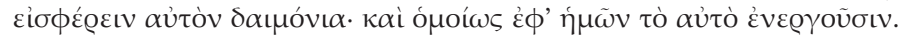

28 Skarsaune (1996: p. 604) is the only scholar who notes the parallelism between the activity of Socrates in Athens and Christian exorcisms: Christ and Socrates "both liberate men from demons, Socrates by unmasking them, Christ by conquering them and breaking their power for good".

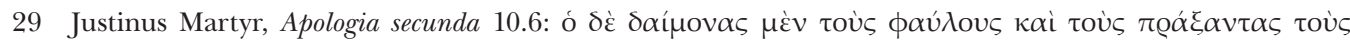

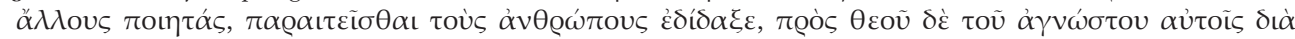

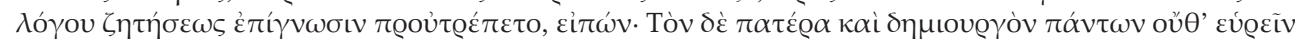

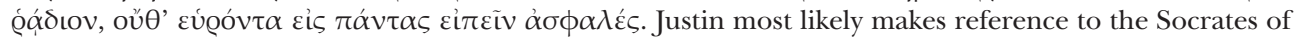
Book II and X of Plato's Respublica.

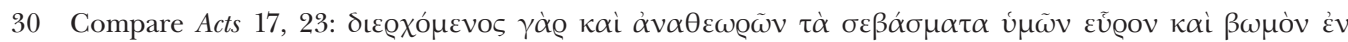

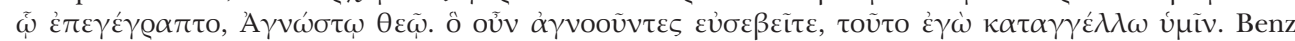
(1951: pp. 206-207), who calls Socrates "frühergeborene Bruder des Apostels" (op. cit., p. 207), argues for intertextuality of Acts and Justin, as does Fédou (1998: p. 61) and Rivas (2003: p. 291). For a detailed discussion of the similarity of Justin's Socrates and Paul of the author of Luke-Acts, see Stegemann (1999: pp. 80-82) and esp. Skarsaune (1996: pp. 589-591), who accepts Socratic typology in Acts and argues that "Justin later 're-modelled' the typological original, Socrates, so that the correspondence became almost 
further, Justin clearly cites Plato's Timaeus, ${ }^{31}$ albeit altering the text slightly to suit his apologetic needs: Discarding the fact that the speaker in Plato's dialogue is not even Socrates, Plato simply claims that it is impossible ( $\dot{\alpha} \delta \dot{v} \alpha \tau o v$ ) to declare the "Father and Maker of all"; for Justin, after the coming of Christ, it is indeed possible, which is why he

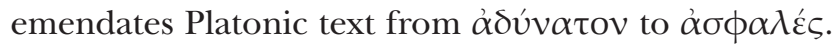

Reserving other interpretations of the $\delta \alpha \iota$ óvıov for section (3) of this paper, which discusses divine inspiration and prophecy, it may be concluded that early Christian writers reference Socratic $\delta \alpha \mu$ óvıov primarily in order to establish the existence of demons, ${ }^{32}$ their existence being necessary for credibility of exorcist practices of Jesus and the Apostles, as well as for the practice of their followers, if we are to believe Justin's reports about exorcisms by ordinary Christians in the second century, which he references as something entirely common..$^{33}$ In the process of defending the existence of demons and their nefarious activities, the figure of Socrates is interpreted in accordance with this primary apologetic aim and it is, ultimately, of little significance whether Socrates comes out of the apologetic meat grinder as a man possessed by a demon or as a proto-exorcist, who wished to ban the priests of these demons from his city, because in both cases he testifies to the existence of demons, and, consequently, legitimizes exorcism as a means of authenticating the gospel of Jesus and his followers.

\section{(2) Argument from moral superiority, martyrdom and the death of Socrates}

In Justin's remarks introduced supra, another line of interpretation of Socrates announces itself - namely that of a just man unjustly put to death. This brings us to the argument from moral superiority, which is most conspicuously exemplified by early Christian

perfect." (op. cit., p. 591). The most complete argument in favour of the presence of Socratic paradigm in Paul's speech at Areopagus (without dealing in detail with Justin's works) is provided by Sandnes (1993: esp. pp. 21-22). It is also worth noting that in the process of making a monotheist out of Socrates, Justin completely ignores the fact that the original accusation against Socrates (which he himself quotes) refers

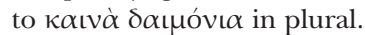

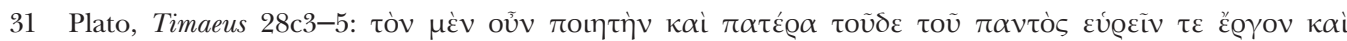

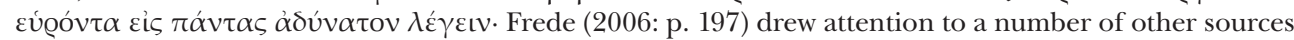
that interpret this section just like Justin does; see, for instance, Flavius Josephus, Contra Apionem 2.224-

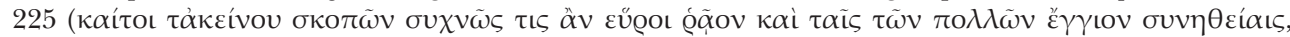

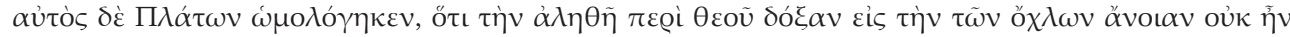

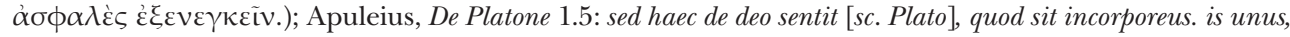

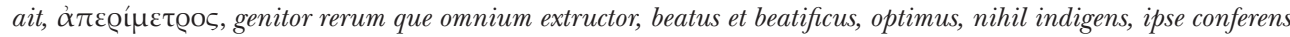

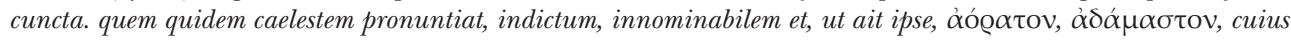
naturam invenire difficile est, si inventa sit, in multos eam enuntiari non posse.

32 This much has been already observed by Melissoni (1930: p. 153): "Il demone socratico contribuisce dunque a confermare presso i Cristiani la fede nella esistenza di genî malvagi nel mondo antico".

33 Justinus Martyr, Apologia secunda 5.5. For Justin's demonology, see esp. Korteweg (2011). Skarsaune (1996: pp. 591-594) further argues that the negative interpretation of demons as fallen angels is typically Jew-

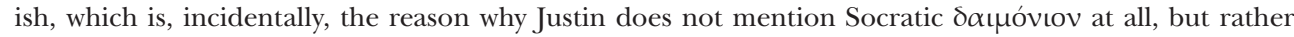
portrays the man himself as an exorcist. 
martyrs, and, above all, by the death of Jesus himself. The noble death of Socrates in face of what was almost unequivocally perceived by pagans and Christians alike as a paradigmatic example of judicial failure provided a welcome parallel with other instances of similar judicial failures - namely those suffered by persecuted Christians.

Setting aside the complicated discussion about the origins and the specific character of Christian martyrdom, ${ }^{34}$ for the purposes of the argument expounded here, it is sufficient to recognize that one of the functions of a martyrdom story is epistemic justification of the beliefs held by the martyr, who, quite literally, witnesses or testifies to the truth of whatever they are putting their lives on the line for. It is hardly satisfactory to define martyrdom as a "type of narrative which describes a death which reinforces a group's (whether religious, political or national) view of the world", as Middleton does. ${ }^{35}$ In order to do justice to the phenomenon of martyrdom, it is necessary to consider also its outward emanation to those who are precisely not (yet) part of the group and for whom the death of the martyr legitimizes the beliefs he or she may hold. Candida Moss puts it in very straightforward terms, which nevertheless highlight the centrality of epistemic justification in early Christian martyrdom narratives, when she writes that "[f]or much of the Christian era, martyrdom was viewed [...] as an indication of Christianity's unique possession of religious truth. If Christians alone were prepared to die for their beliefs, it was thought, then there must be something special about Christianity." 36

The parallel between unjustly condemned Socrates and unjustly condemned Christians has been felt so strongly that the Greek philosopher is explicitly named in several acts of early martyrs. For instance, in Acta Apollonii, we read: ${ }^{37}$

34 Frend (2008: pp. 31-78) famously stressed the importance of Jewish influences in construction of Christian martyrdom, arguing that "if one considers martyrdom in terms of witness to God's mighty works, and the martyr as His agent, Christians looked back almost exclusively to Jewish prototypes" (op. cit., p. 67). He does not completely discard any influence pagan antiquity might have had on early Christian martyrs (op. cit., pp. 65-66, naming Socrates explicitly), however, he cautiously adds that "much of the self-sacrifice was on behalf of avowedly political causes" (op. cit., p. 66). Van Henten (2012: p. 104) rightly emphasized the fact that the "martyrdom" of Socrates was religiously - and not politically - motivated, concluding that "Socrates' attitude towards death has functioned as a model for others in various contexts, especially from the first century AD onwards" (ibid.). Contrary to Frend, Bowersock (1995: p. 5) claimed that Christian martyrdom is "something entirely new". He recognizes the possible influence of the Socratic model (along three Jews in the furnace of Daniel, both as tokens of pagan and Jewish influences), yet claims that "never before had such courage been absorbed into a conceptual system of posthumous recognition and anticipated reward, nor had the very word martyrdom existed as the name of this system" (ibid.). A good critical discussion of these two competing approaches is found in Boyarin (1999: pp. 93-126), who (quite sensibly) opposes any sharp delineations and emphasizes the complications connected with any attempt to separate clearly Jewish and Christian models in the first centuries CE.

35 Middleton (2006: p. 13).

36 Moss (2012: p. 23). Similar assessment is found in MacMullen (1981: p. 135), who aptly interprets martyrdom as a miracle sui generis, thus linking it to the other mode of epistemic justification that has been discussed in section (1): "Surrender of one's life for one's faith was bound to work most powerfully on witnesses. It was quite beyond nature, a wonder. Along with miracles of other kinds and exorcism [...], it goes far to explain how thousands, not mere dozens of the uncommitted, might be induced really to look at another man's god and really to open their minds to a new reality."

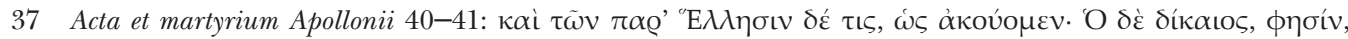

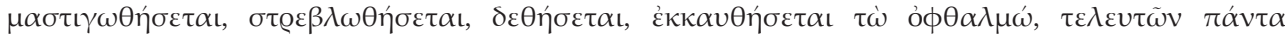


"So too one of the Greeks has written for us to hear: 'The just man', he says, 'will be whipped, tortured, bound, his eyes gouged out, and after suffering all sorts of penalties will finally be impaled on the gallows.' The Athenian informers convinced the people and then unjustly condemned Socrates; so too our Saviour and teacher was condemned by a few malefactors after they had him bound." (transl. H. Musurillo)

These and similar statements ${ }^{38}$ may amount to simple parallelisms or gratuitous comparisons which somehow "naturally" spring to mind of well-educated authors, ${ }^{39}$ but the comparison of the death of Socrates to the death of Jesus and Christian martyrs may be rooted in some deeper apologetic purposes, in particular in early attempts to respond to the $\sigma \kappa \alpha \dot{v} \delta \alpha \lambda$ ov-objection to the cross of Jesus, that has been voiced from the pagan as well as Jewish backgrounds, for whom the narrative about a Messiah dying a criminal's death was hardly persuasive.

This much is clear from the discussions in Origen's work Contra Celsum. When pagan philosopher Celsus argues that Jesus, knowing in advance what will befall him - that is to say, trial, unjust sentence and death -, would be foolish in not trying to escape it if it were in his power (and it is, of course, assumed that it should have been in Jesus' power; therefore Jesus is a foolish man, not God's Holy One), Origen answers thus: ${ }^{40}$

"And yet Socrates knew that he would die after drinking the hemlock, and it was in his power, if he had allowed himself to be persuaded by Crito, by escaping from prison, to avoid these calamities; but nevertheless he decided, as it appeared to him consistent with right reason, that it was better for him to die as a philosopher, than to retain his life and cease to be one." (transl. F. Crombie)

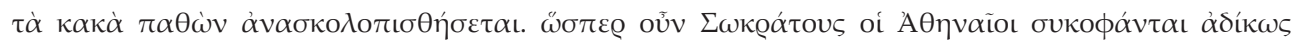

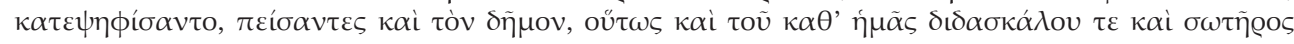

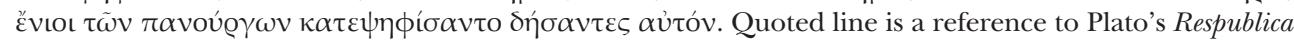
361e4-362a3, see esp. Benz (1950).

38 See also Martyrium Pionii presbyteri et sodalium 17.2-3, where Pionius counters Rufinus' rebuke ( $\mu$ ì

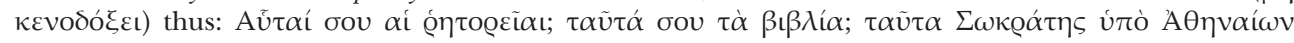

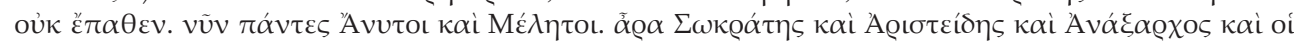

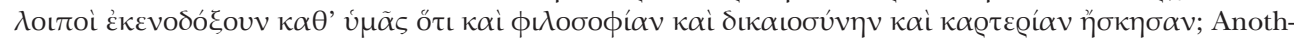
er attestation, however likely of post-Nicene origin, is found in one of the Greek versions of Acta Phileae (Papyrus Chester Beatty XV; the other Greek version, Papyrus Bodmer XX, does not contain the reference). For the in-depth discussion of all the references to Socrates in martyrological texts, see Roskam (2010).

39 Benz (1951: p. 219) suggests that the references to the trial and death of Socrates in the martyrdom literature are not to be considered literary тó same idea, with respect to Origen in particular, is espoused by Melinossi (1930: p. 139): "sorge spontaneo il confronte della morte di Socrate con il martirio di Cristo". Bakker (2015: p. 392) also highlights the ad hoc use of the Socratic figure (specifically with respect to the Acts of Apollonius), claiming that "Socrates is only introduced to indicate that Christianity is a respectable faith, and that Christians share some of their basic perspectives with the famous philosopher", while adding that "this seems to be the case in almost all Christian texts in which the person of Socrates is referred to".

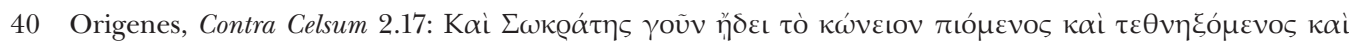

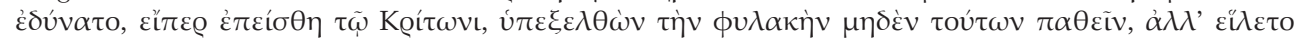

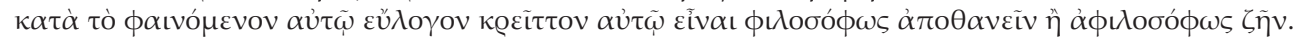


In the seventh book of Contra Celsum, the same line of argument is pursued further, with similar apologetic aims of legitimizing seemingly very inglorious death: ${ }^{41}$

"Jesus did indeed meet with a most sad death; but the same might be said of Socrates, and of Anaxarchus, whom he [sc. Celsus] had just mentioned, and a multitude of others. If the death of Jesus was a miserable one, was not that of the others as well? And if their death was not miserable, can it be said that the death of Jesus was?” (transl. F. Crombie)

Origen uses the death of Socrates as an argument against the $\sigma \kappa \alpha \dot{\alpha} \delta \alpha \lambda$ ov of Jesus' death - if it was noble for one of the greatest philosophers of the Greeks to die willingly, it is inconsistent to argue that it is ignoble for Jesus to do so (and, by extension, for Christian martyrs). Origen thus brings our attention to the "noble death" paradigm, ${ }^{42}$ which recent scholarship identified as an important source of inspiration for narratives of Jesus' death, as well as the deaths of the early Christian martyrs.

While Socrates is not named explicitly anywhere in the writings of the New Testament, several scholars have argued persuasively that the Socratic paradigm of noble death looms behind Lukan passion, which in many respects differs from the earlier two gospel traditions. ${ }^{43}$ In Mark and $Q$, text with comparatively low Christology, the portrayal of Jesus facing death is considered to be "all too human", which is precisely what the author of Luke-Acts remedies by modelling, at least in some respects, the passion of Jesus on the death of Socrates.

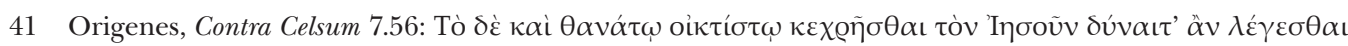

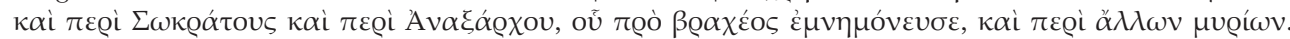

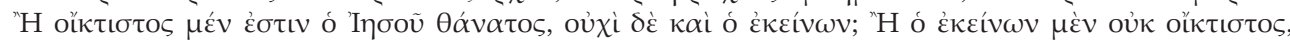

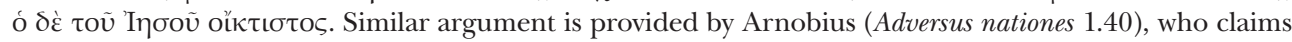
that the mere fact of a forced death cannot nullify the life of the individual: Similiter Socrates civitatis suae iudicio damnatus capitali adfectus est poena: numquid inrita facta sunt quae sunt ab eo de moribus, virtutibus et officiis disputata, quia iniuria expulsus e vita est? Müller (1986: p. 72) considers these texts to be strikingly different from similar statements by Justin, such as those discussed in section (1), because he misses the reductio ad absurdum argument that is likely operating here. Origen is, of course, not really claiming that

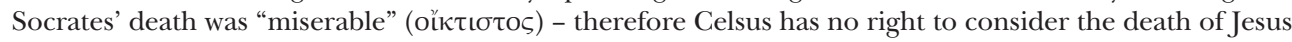
"miserable".

42 Van Henten \& Avemarie (2002) collected the most important texts related to "noble death" type in Jewish, pagan and Christian antiquity (with portions of Plato's Apology included). See also Droge \& Tabor (1992); Van Henten (2012); and Middleton (2006: pp. 116-123), who singles out Socrates as a prime example of "noble death" in the realm of philosophy (op. cit., p. 116).

43 The numerous naïve parallelism-studies between Socrates and Jesus, of which Bostick (1935) would be a representative example, need not be mentioned here. Kloppenborg (1992) emphasized the considerable length of the Last Supper scene in Luke (compared with Mark and Matthew) and its connection with Greek symposia, implied presence of the disciples through Jesus' passion (cf. Plato's Phaedo) and the composure of Jesus while facing death (again compared with Markan account). Sterling (2001) likewise stressed numerous parallels between the Lukan passion and the death of Socrates, concluding that "the evangelist carefully reworked the death of Jesus at critical points to remind the hearer/reader of Socrates, the paradigmatic martyr of his society" (op. cit., p. 401). In a recent critical reaction to these interpretations, Tabb (2015) highlights differences, rather than similarities, between the death of Jesus in Luke and the death of Socrates (op. cit., p. 293-295), claiming that "Jesus' death in Luke shares more affinities with the violent death of the prophets and the persecution of the righteous than with Jewish martyrdoms or the death of Socrates" (op. cit., p. 300). 
Stephanie Cobb argued in a similar vein for close parallels between the death of Socrates and the martyrdom of Polycarp, highlighting sacrificial imagery, imperviousness to physical limitations, endurance, and submission to the divine will, all of which serve as an exemplum for others to follow. ${ }^{44}$ Using Socrates as a model, the author of the Martyrdom of Polycarp vindicates not only the death of Polycarp, but through Polycarp also that of Jesus. In her own words, "the presence of elements from the noble death tradition may function more broadly to relate both Polycarp and Jesus to the paradigmatic martyr, Socrates. Imitatio Socratis in this text, in other words, creates the appearance of nobility in death not only for Polycarp but also for his model, Jesus: the various parallels in the Martyrdom of Polycarp recount the imitation-worthy actions of the aged bishop while simultaneously recasting the death of his Lord as a noble death." ${ }^{45}$ The author of the Martyrdom of Polycarp, then, extends the strategy employed already by the author of Luke-Acts by re-contextualizing the $\sigma \kappa \alpha ́ v \delta \alpha \lambda$ ov of the death of the Messiah on the cross and presenting it as a "noble death". Similar claims have been advanced with regard to Perpetua's passio ${ }^{46}$ and Justin's use of the death of Socrates. ${ }^{47}$

However, not all early Christian apologists were persuaded that the "noble death" of Socrates could serve as an exemplum for Christian martyrs or as a vindication of Jesus' own death. ${ }^{48}$ Quite unsurprisingly, it is Tertullian who casts doubts on Athenian's comportment during his last hours, and he does so in a lengthy section that serves as an opening to his treatise De anima ${ }^{49}$ unflatteringly described by Ernst Dassmann as "bossy and nitpicking" ("rechthaberisch und kleinlich"). ${ }^{50}$ Socrates, in Tertullian's view, could not have been as calm and composed as the sources tell us - and even if we grant this to be true, "his soul must have been moved even by its very efforts to suppress emotion; and his constancy itself must have been shaken, as he struggled against the disturbance

44 Cobb (2014).

45 Cobb (2014: p. 237).

46 Sissa (2012: p. 253) claims (without any relevant argument) that "even if we reject the hypothesis that the young convert might have ever read the Phaedo, let alone re-read it in prison, like Cato, the way she projects herself in those final hours resonates strikingly - pace Tertullian - with the Platonic construction of the perfect martyrdom". Sissa leaves the question of Tertullian's authorship of the passio open (op. cit., p. 253, n. 17), unnecessarily so - see Kitzler (2015: p. 17-19), who concludes that the rejection of Tertullian as author is "inevitable" (op. cit., p. 19).

47 Rivas (2003: p. 292): "Los cristianos del tiempo de Justino necesitaban un ejemplo cercano en la tradición en la que ellos fueron educados. Como la mención de la muerte de Jesús en la cruz no era «bien vista» por los mismos cristianos en ese período (las alusiones en la obra de Justino son más bien escasas), se hacía necesario encontrar un personaje de la historia que encarnara el espíritu del Evangelio y a la vez sea ejemplo de valor y fortaleza ante el martirio."

48 This is largely the position of Latin ante-Nicene writers, for whom the model for "noble death" is Seneca, not Socrates, as Stegemann (1999: pp. 84-85) showed.

49 Tertullianus, De anima 1.2-6. This section is discussed in some detail by Döring (1999: pp. 62-64) and Sissa (2012: pp. 249-251). As Carlson (1948: pp. 96-98) pointed out, Socrates is also conspicuously missing from Tertullian's lists of pagan bravery and fortitude (Apologeticum 50.5-9; Ad martyras 4.4-8; Ad nationes 1.18.3-4).

Dassmann (1993: p. 41). 
of the excitement around him" ${ }^{51}$ His wisdom "proceeded from the affectation of an assumed composure, rather than the firm conviction of ascertained truth", ${ }^{52}$ because, as Tertullian is quick to point out, there can be no knowledge of truth without God, no knowledge of God without Christ, and no knowledge of Christ without the Holy Spirit. Yet Socrates could not have been attended by Holy Spirit, but only by a different kind of a being, namely his evil demon. In what follows, Tertullian provides a striking counterpoint to the attempts to dignify the death of Jesus and the early martyrs through Socratic example and it is worthwhile to quote it in full: ${ }^{53}$

\begin{abstract}
"This wisdom of the school of heaven frankly and without reserve denies the gods of this world, and shows no such inconsistency as to order a 'cock to be sacrificed to Aesculapius': no new gods and demons does it introduce, but expels the old ones; it corrupts not youth, but instructs them in all goodness and moderation; and so it bears the unjust condemnation not of one city only, but of all the world, in the cause of that truth which incurs indeed the greater hatred in proportion to its fullness: so that it tastes death not out of a [poisoned] cup almost in the way of jollity; but it exhausts it in every kind of bitter cruelty, on gibbets and in holocausts." (transl. P. Holmes)
\end{abstract}

For Tertullian, there can hardly be any parallelism between the death of Socrates and the death of Christian martyrs (to speak nothing about the death of Christ), ${ }^{54}$ and while it has been shown that other early Christian writers clearly drew the connection between the two, they certainly did not equate them in merit. ${ }^{55}$ Tertullian notwithstanding, it may be concluded that early Christian writers considered - by and large - the conduct of Socrates facing death to be admirable - so much, in fact, that they did not hesitate to

51 Tertullianus, De anima 1.2: in hoc tamen mota [sc. anima], ne moueretur, ipsa constantia concussa est aduersus inconstantiae concussionem.

52 Tertullianus, De anima 1.4: omnis illa tunc sapientia Socratis de industria uenerat consultae aeqanimitatis, non de fiducia compertae ueritatis.

53 Tertullianus, De anima 1.6: Haec sapientia de schola caeli deos quidem saeculi negare liberior, quae nullum Aesculapio gallinaceum reddi iubens praeuaricetur, nec noua inferens daemonia, sed uetera depellens, nec adulescentiam uitians, sed omni bono pudoris informans, ideoque non unius urbis, sed uniuersi orbis iniquam sententiam sustinens pro nomine ueritatis tanto scilicet et perosioris quanto plenioris, ut et mortem non de poculo per habitum iocunditatis absorbeat, sed de patibulo et uiuicomurio per omne ingenium crudelitatis exhauriat.

54 While not directly relevant to the discussion limited to ante-Nicene literature, it is interesting to note that the negative assessment of the trial of Socrates in comparison with the "trial" of Augustine's mother Monnica (Confessiones 9.13.34-37) has been argued for by Stróżyński (2014), who claims that "nothing can be more contrary than Monnica's and Socrates' attitudes before the court" (op. cit., p. 127) and that "Augustine seems to give his readers a choice - they can act like Socrates (or any 'rational' defendant), or they can act like Monnica (in her trust in the folly of the cross)" (op. cit., p. 131).

55 Frede (2006: p. 195) observes that early Christian authors "were not prepared to grant that Socrates, with his life and death, had set an example of any positive relevance to Christians. To have granted more to Socrates would have undermined their case against pagan philosophy". The identical point is argued for by Müller (1986: p. 76): "Aufs Ganze gesehen wird man urteilen müssen, daß man sich in der Alten Kirche zwar nicht scheute, Sokrates in eine Reihe mit Märtyrern (oder auch mit verfolgten Propheten) zu stellen, daß man aber eine Nebeneinanderstellung des Todes Jesu und jenes des Sokrates in der Regel als unangemessen empfand.” 
delineate analogies between the death of Socrates on one side and the death of Jesus and the death of the martyrs on the other, while cautiously denying them pari passu evaluation.

However, stories of Christian martyrs who sacrifice their own lives in order to witness the truth of their beliefs form only one facet of the epistemic justification by the moral conduct of the speakers. Just like the superior moral behaviour is considered to signalize truth of the belief held by the actor, immoral behaviour is conversely seen as an indication of its falsity. It is not surprising, therefore, that early Christian literature contains numerous references to what amounts to an immoral behaviour on the part of Socrates (at least if seen from their perspective)..$^{56}$

Early Christian authors focused mainly on matters of Socrates' "illicit" sexual relationships. Pseudo-Clemens of Rome provides a good picture of this critique: ${ }^{.7}$

"Do not the celebrated philosophers extol pleasure, and have they not had sex with all the women they could? Of these the first was that teacher of Greece, of whom Phoebus himself said, 'Of all men, Socrates is the wisest.' Does not he teach that in a well-regulated state, women should be common? And did he not conceal the fair Alcibiades under his philosopher's gown?" (transl. T. Smith)

When Tertullianus criticizes sexual morality, he suggests that pagans are simply "following the example, I believe, of those wise men of ancient times, the Greek Socrates and the Roman Cato, who shared with their friends the wives whom they had married [...] O noble example of Attic wisdom, of Roman gravity - the philosopher and the censor playing pimps!" 58 Several chapters later, it is homosexual orientation that provides Tertullianus with an opportunity to criticize pagan sexual morality: ${ }^{59}$

"But if we challenge you to comparison in the virtue of chastity, I turn to a part of the sentence passed by the Athenians against Socrates, who was pronounced a corrupter of youth. The Christian confines himself to the female sex." (transl. S. Thelwall)

This short section may be seen as representative for the early Christian interpretations of Socrates in general. The text and the underlying argument make it clear that Tertul-

56 Melissoni (1930: p. 142) argues that the doctrines of Socrates may be subject to criticism in early Christian literature, yet "unanime risulta invece il giudizio sulla sua figura morale, che, se rifulse incontrastata nel mondo antico, è circondata d'ammirazione anche nel Cristianesimo, Tertulliano compreso”. Following discussion shows why assessments like these are one-sided and untenable.

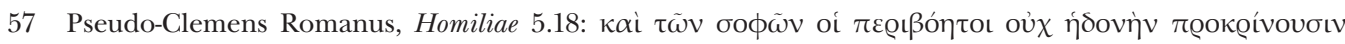

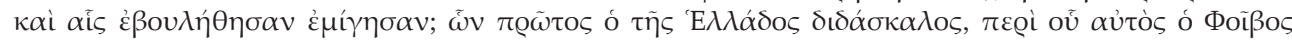

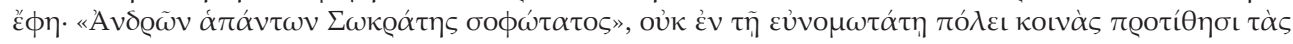

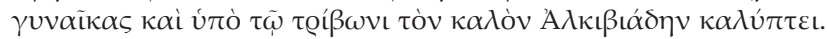

58 Tertullianus, Apologeticum 39.12-13: [...] ex illa, credo, maiorum et sapientiorum suorum disciplina, Graeci Socratis et Romani Catonis, qui uxores suas amicis communicauerunt [...] O sapientiae Atticae, o Romanae grauitatis exemplum: leno est philosophus et censor!

59 Tertullianus, Apologeticum 46.10: Ceterum si de pudicitia prouocemur, lego partem sententiae Atticae in Socratem: corruptor adulescentium pronuntiatur. Christianus ad sexum nec femina mutat. On Socrates' pederasty in connection with his role as a pedagogue see esp. Bady (2005). 
lian considers the sentence passed by Athenians against Socrates as a just one, while on other occasions - namely when he wants to highlight the fact that truth is always persecuted - he clearly assumes the contrary and considers the sentence to be an unjust one. ${ }^{60}$ The respective evaluations are completely dependent on the ad hoc argumentative point Tertullian happens to be making.

To summarize the interpretations of the figure of Socrates discussed in this section, allusions to the Athenian philosopher are once again guided by one single apologetic aim, which vindicates the principle according to which noble moral behaviour, and more specifically, the ability to stand by one's beliefs even in face of impending death, epistemically justifies these beliefs. Likewise, the ignoble moral behaviour is connected with falsity of the beliefs held by those who behave inappropriately. The interpretation of Socrates is, accordingly, a positive one whenever he serves as an analogue to the death of Jesus and to the death of the martyrs; the interpretation is a negative one whenever the emphasis shifts to his alleged polygamy and homosexuality. Both interpretations, however, are mirror images of each other when perceived through the prism of epistemic justification by means of ad hominem arguments from authority based on superior (or inferior) moral behaviour.

\section{(3) Argument from divine inspiration, prophecy and Socrates at Delphi}

I move now to another important element of Socratic reception in early Christianity, which lies in the realm of divine inspiration and prophecy. The full exposition of this important issue cannot be attempted here ${ }^{61}$ yet it is sufficient to presuppose that the argument from divine inspiration and prophecy clearly serves - among other arguments introduced in previous sections - to epistemically justify the beliefs propounded by Jesus and his immediate followers ${ }^{62}$ With respect to the figure of Socrates, the issue of divine inspiration and prophecy is conceptualized under three rubrics: First, early Christian

60 This is the case especially in the earliest works, see Tertullianus, Ad nationes 1.4 .6 (Socrates ex ea parte damnatus est, qua propius temptauerat ueritatem, deos uestros destruendo: quamquam nondum tunc in terries nomen Christianum, tamen ueritas semper damnabatur.); Apologeticum 46.7 («Sed propterea damnatus est Socrates, quia deos destruebat». - Plane olim, id semper est, ueritas odio est.). Opelt (1983: p. 195) hypothesizes that this shift from fairly accommodative interpretation to the complete rejection of Socrates as a possible positive model in his later works is due to Tertullian's conversion to Montanism, yet this does not seem to be true. Döring (1999: pp. 59-62) showed that there are more negative than positive assessments of Socrates already in Tertullian's Apologeticum.

61 Aune (1983) remains one of the best introductions to prophecy in early Christianity.

62 Even authors as diverse as Justin and Tertullian agree on this point, see, for instance, Justinus Mar-

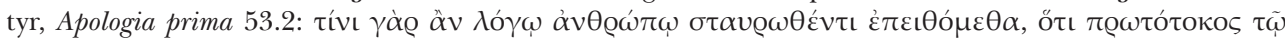

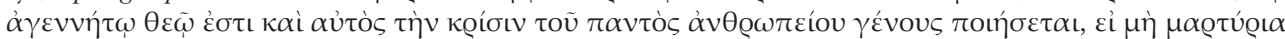

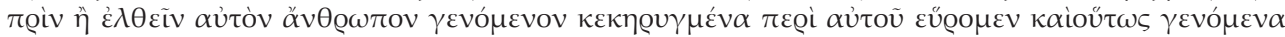
$\dot{\varepsilon} \omega \hat{\varrho} \tilde{\omega} \mu v$; Tertullianus, Apologeticum 20.2-3: Quicquid agitur, praenuntiabatur; quicquid uidetur, audiebatur [...] Dum patimur, leguntur; dum recognoscimus, probantur. Idoneum, opinor, testimonium diuinitatis ueritas diuinationis. Justin's "proof from prophecy" has been extensively studied by Skarsaune (1987). 
authors were interested in a narrative about Socrates and his dream about the swan; second, in his $\delta \alpha$ uóvıov; and third, in the Delphic oracular response that proclaimed Socrates the wisest of all humans, thereby initiating his philosophical "mission" in Athens.

When Origen defends Christianity against a skeptical pagan philosopher denying any

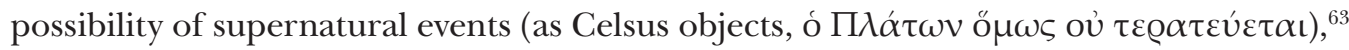
he highlights the most salient instances of the supernatural in the Greek philosophical tradition, discussing at length especially the figure of Pythagoras - his ivory thigh and the uncanny ability to be present at two different places at once. Then he moves to Socrates and recounts his dream of the swan, prefiguring the first meeting with his most famous disciple, Plato: ${ }^{64}$

"He, moreover, who will declare that what is related of Plato and Socrates is a marvelous fic-
tion, will quote the story of the swan which was recommended to Socrates while he was asleep,
and of the master saying, when he met the young man, 'This, then, was the swan!' [...] But oc-
casion for slanderous accusations will never be wanting to those who are ill-disposed [...] and
such persons will deride as a fiction even the demon of Socrates." (transl. F. Crombie)

Barring the reference to Socratic $\delta \alpha \iota \mu$ óvıov as a supernatural element, the story Origen relates is also found in a more complete form in Apuleius' De Platone ${ }^{65}$ One day, Socrates had a dream in which a cygnet (pullum cygni) is being transformed into a swan (olor) at the altar of the Cupid at the Academia. Next day, when he recounts this dream to a group of friends and when Ariston introduces him to young Plato, still a boy, Socrates recognizes him as the swan from the dream. Origen's implied argument behind this narrative is clear: Celsus - as an heir to the Greek philosophy - has no right to criticize the supernatural elements in Christianity, since they form part and parcel of the tradition of pagan wisdom.

Further emphasis on the prophecy is found especially in the writings of Clemens of Alexandria. When Clemens defends the power of prophecy, he does not hesitate to turn to precedents supplies by Greek philosophical tradition, pointing out that "Pythagoras took part in divination [...] and in addition to these, Socrates the Athenian in particular. For, he says in the Theages, 'I am attended by a supernatural intimation, which has been assigned me from a child by divine appointment. This is a voice which, when it comes,

63 Origenes, Contra Celsum 6.8.

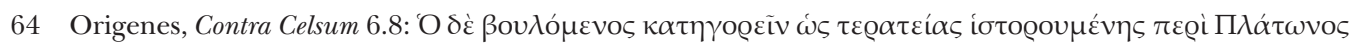

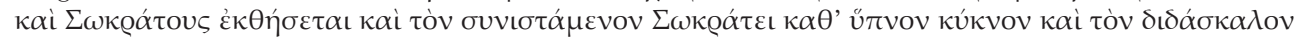

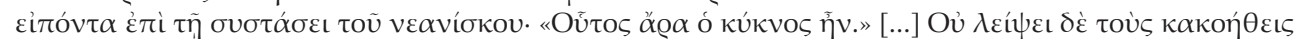

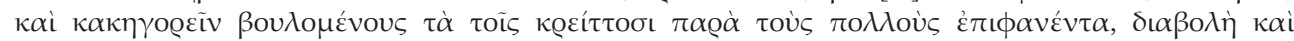

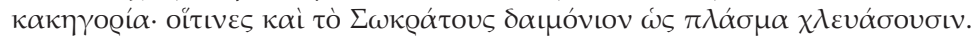

65 Apuleius, De Platone 1.1.182-183: somnium etiam Socratis scitum ferunt: nam vidisse sibi visus est cygni pullum ex altari, quod in Academia Cupidini consecratum est, volasse et in eius gremio resedisse et postea olorem illum pinnis caelum petisse, canore musico auditus hominum deorumque mulcentem. cum hoc Socrates in conventu amicorum referret, Ariston Platonem puerum oblaturus Socrati magistro commodum prosequebatur. quem ubi adspexit ille ingeniumque intimum de exteriore conspicatus est facie: 'hic ille erat, amici', inquit, 'de Academia Cupidinis cygnus'. This story is also alluded to by Tertullianus, De anima 46.9: Cycnus de sinu Socratis demulcens homines discipulus Plato est. 
prevents what I am about to do, but exhorts never." ${ }_{66}^{6}$ If we compare Clemens' interpretation of Socratic $\delta \alpha \mu$ óvıov with those found in section (1), it becomes immediately apparent that Socratic supernatural experience is being interpreted in Stromata with

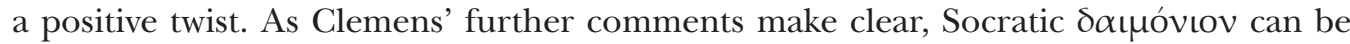
conceptualized as a prototype of divine inspiration: ${ }^{67}$

"And in general, Pythagoras, and Socrates, and Plato say that they hear God's voice while closely contemplating the fabric of the universe, made and preserved unceasingly by God. For they heard Moses say, 'He said, and it was done,' describing the word of God as an act." (transl. W. Wilson)

While Clemens usually claims that Greeks stole their wisdom from the Hebrews ${ }^{68}$ he occasionally seems to propose an alternative theory as well, according to which divinely inspired men (such as Socrates) function analogically to Old Testament prophets. ${ }^{69}$ Additionally, this argument serves as an antidote to those skeptical pagans who would deny the power of prophecy and divine inspiration tout court. An educated Greek can hardly

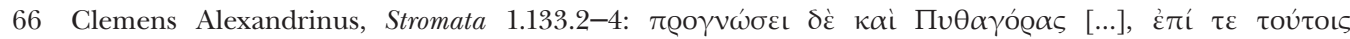

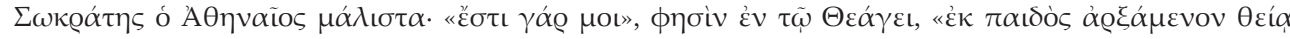

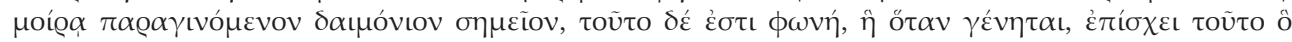

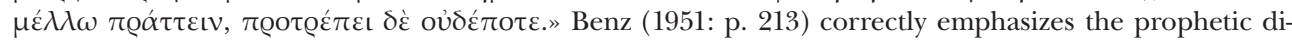
mension of Socratic $\delta \alpha$ นóvıov in Clement, in spite of its negative connotations in most of the Christian texts: "Clemens hat sogar kein Bedenken, das Daimonion des Sokrates, das einem Christen schon durch seinen Namen anstößig erscheinen mußte, als einen Engel zu deuten und die Wirkung dieses Daimonions mit der Wirkung des in den Propheten wirkenden Geistes in Zusammenhang zu bringen.” The role of Socrates as a "prophet" is discussed further by Bakker (2015: pp. 404-407).

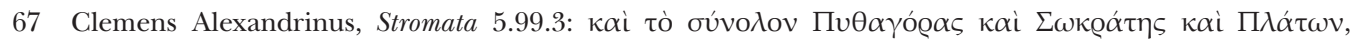

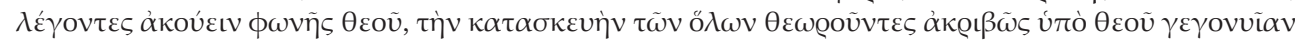

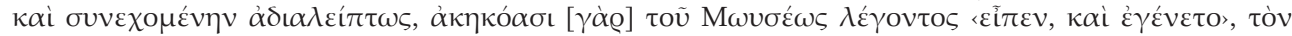

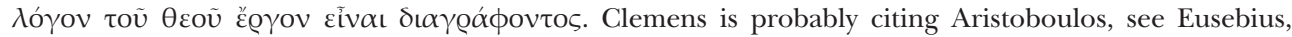

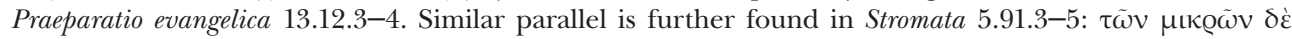

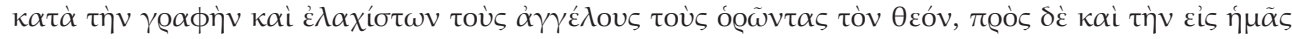

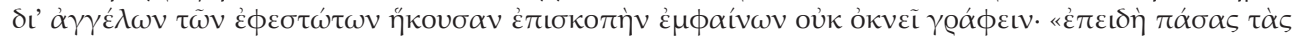

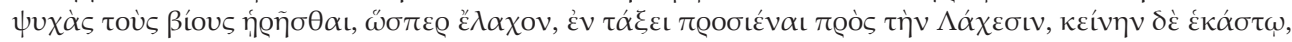

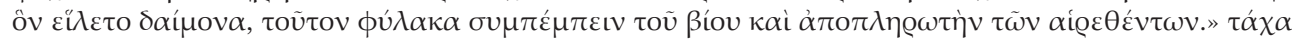

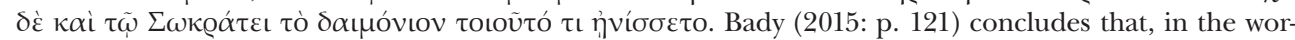

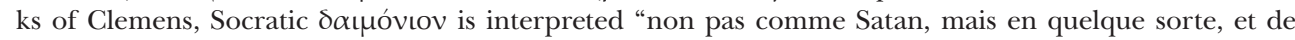
façon aussi rare que paradoxale, comme un ange gardien"; according to Edwards (2007: p. 130), Clemens "speaks both knowledgeably and tolerantly of Socrates' daimon, almost characterizing him as a guardian

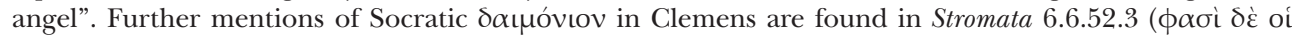

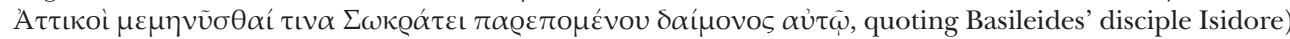

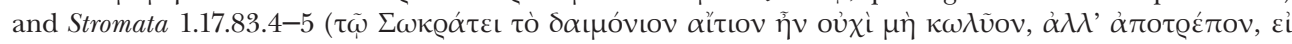

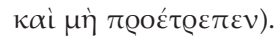

68 See especially Clemens Alexandrinus, Stromata 5.5-34 and passim.

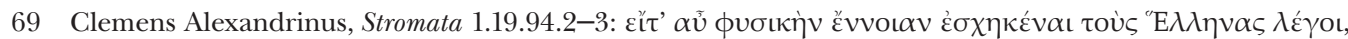

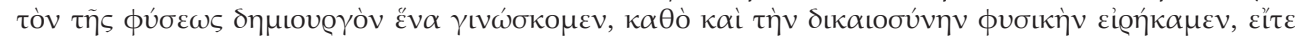

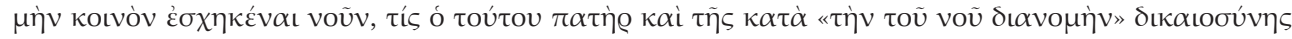

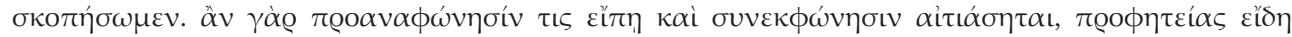
$\lambda \varepsilon \dot{\gamma \varepsilon \varepsilon .}$ 
reject prophecy without rejecting a good part of their own philosophical tradition with it. ${ }^{70}$ Continuing with the theme of prophecy, early Christian writers often comment on a famous episode related in Plato's Apology, where Chairephon is said to have asked the Delphic oracle whether there is anyone wiser than Socrates, only to be met with a negative answer. ${ }^{71}$ Origen, for instance, refuses to accept the oracular utterance as true, even suggesting that Socrates might have essentially bribed Apollo: ${ }^{72}$

\begin{abstract}
"And perhaps it was not so much in regard to his philosophy that he called Socrates the wisest of all men, as on account of the victims which he sacrificed to him and the other demons. For it seems that the demons pay more regard in distributing their favours to the sacrifices which are offered them than to deeds of virtue." (transl. F. Crombie)
\end{abstract}

Origen, who, as we have seen, has previously used Socrates' dream about the swan to argue for the possibility of prophecies and other supernatural events (in book 6 of Contra Celsum), will however give no credit to pagan oracles (in book 7 of Contra Celsum), yet other Christian writers approached the problem from quite a different angle. Tertullian, for instance, in a piece of playful rhetoric, accepts the oracular response only to destroy its source: ${ }^{73}$

"Yet he [sc. Socrates], too, though in denying the existence of your divinities he had a glimpse of the truth, at his dying ordered a cock to be sacrificed to Aesculapius, I believe in honour of his father, for Apollo pronounced Socrates the wisest of men. Thoughtless Apollo, testifying to the wisdom of the man who denied the existence of his race!" (transl. S. Thelwall)

In concert with sections (1) and (2), we find an ambiguous interpretation of Socrates also with respect to the justification of early Christian beliefs by prophecy and divine inspiration. Socratic dream about the swan serves as an argument for the existence of prophecy; his $\delta \alpha$ เóvıov is interpreted by Clemens as a guardian angel or a sort of divine inspiration, while the testimony of the Delphic oracle is ridiculed as pagan nonsense. The overall interpretation, then, may be positive or negative, but both are guided

70 Xenophon explicitly connects Socratic demonic experience with divination, see Memorabilia 1.1.3-4; Jedrkiewicz (2011: pp. 237-238) and especially Zaidman (2013).

71 Plato, Apologia 20e8-21a8.

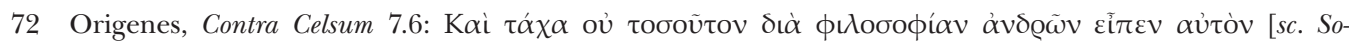

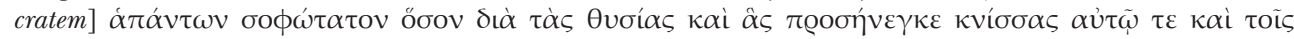

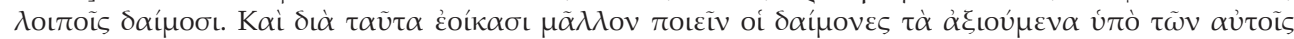

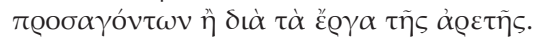

73 Tertullianus, Apologeticum 46.5-6: Idem et qui aliquid de ueritate sapiebat deos negans, Aesculapio tamen gallinaceum prosecari iam in fine mandabat, credo, ob honorem patris eius, quia Socratem Apollo sapientissimum omnium cecinit. O Apollinem inconsideratum! sapientiae testimonium reddidit ei uiro, qui negabat deos esse. A variation on this theme is also found in his Ad nationes 1.4.7: Vicit Apollinem ueritas, ut ipse aduersus se pronuntiaret; confessus est enim se deum non esse, sed eum quoque sapientissimum affirmans qui deos abnuebat. 
by the single principle of epistemic justification intended to legitimize divine inspiration and prophecy as valid arguments for the truth of the Christian beliefs. ${ }^{74}$

\section{(4) Human "wisdom" and Socratic profession of ignorance}

Although the more general relation of early Christian writers to pagan wisdom, represented by Greek and Roman philosophy, cannot be treated here in any detail, it is in my opinion safe to assume that all of early apologists and theologians assumed a stance in which the achievements of philosophy play only a secondary role next to the truth of revelation that has been consistently defended by appeals to miracles, superior moral behaviour and divine inspiration manifested in prophecies. Even authors openly hostile to the philosophers, of which Tertullian would be a prime example, ${ }^{75}$ did not deny that pagan wisdom (or, more generally, reason unaided by revelation) might have contained a modicum of truth; ${ }^{76}$ on the other hand, the apologists that have been shown to be most accommodative of philosophy, such as Justin, who did not hesitate to call Socrates a Christian, ${ }^{77}$ consistently argued for superiority of revelation in face of any and all knowledge that has been arrived at by earthly means. ${ }^{78}$ This section will therefore

74 Any positive connotations of the Socratic $\delta \alpha \mu$ óvıov are canonically extinguished by Augustine, who in the discussion of Apuleius' De deo Socratis challenges the role of demons as mediators between the human and the divine and replaces it with Jesus as mediator, see esp. recent study by Saudelli (2014). As Edwards (2007: p. 140) concluded, "Augustine and his Neoplatonic tutors ensured that the questing, diffident Socrates of the Sceptics would pass out of the Christian memory for a millennium”.

75 The loci classici of the juxtaposition of philosophy and faith in Tertullian are esp. De carne Christi 5.4 (Crucifixus est dei filius; non pudet, quia pudendum est. Et mortuus est dei filius; credibile est, quia ineptum est. Et sepultus resurrexit; certum est, quia impossibile.); De praescriptione haereticorum 7.9 (Quid ergo Athenis et Hierosolymis? quid academiae et ecclesiae? quid haereticis et christianis?); Apologeticum 46.18 (Adeo quid simile philosophus et Christianus, Graeciae discipulus et caeli, famae negotiator et salutis uitae, uerborum et factorum operator, et rerum aedificator et destructor, et interpolator et integrator ueritatis, furator eius et custos?). Labhardt (1950) remains the classical study of Tertullian as an irreconciliable enemy of philosophy and ratiocination, while Bochet (2008) argued recently (and, in my opinion, unpersuasively), for a rationalist interpretation of Tertullian. With respect to some of the sections introduced above, she even claims that "l'usage du paradoxe n'est pas une mise en cause de la raison; plus radicalment même, il en est une exigence” (op. cit., p. 271).

76 See, for instance, Tertullianus, De resurrectione mortuorum 3.1: Est quidem et de communibus sensibus sapere in dei rebus [...] Quaedam enim et naturaliter nota sunt, ut immortalitas animae penes plures, ut deus noster penes omnes.

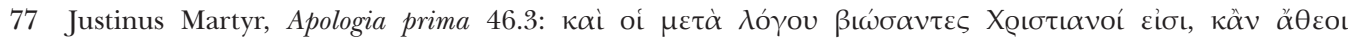

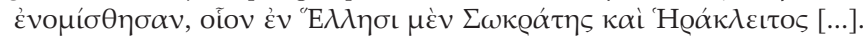

78 See especially Justinus Martyr, Apologia secunda 10. Bakker (2015: p. 404) claims that, in Justin's view, “Socrates was to be seen as a gentile prophet inspired by Christ four centuries before the Logos was actually made flesh. His martyrdom only sealed the universal grace that was already active upon the Athenian teacher." This assessment is certainly overblown and Justin never confounds fragmentary and limited

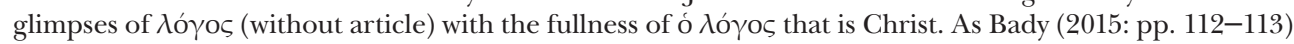
correctly notes, the difference between the two is "de nature et non de degré. S'il y a «accomplissement», c'est par une intervention surnaturelle, reléguant par comparaison Socrate à l'impuissance”. Similarly, Korteweg (2011: p. 146) concludes that Justin's "message, therefore, was certainly not that there could be a harmony between belief and reason, nor that humanity had been gradually educated until Christ, in which process Greek philosophy also made its contribution”. Fédou (1998: pp. 56-57) even argues that the whole point of calling Socrates and other pagan philosophers Christians avant la lettre was to establish 
focus on the use of the figure of Socrates as a means to underscore deficiencies of nonrevealed wisdom which in turn vindicate the epistemic justification ad hominem that has been presented in previous sections.

Closely connected to the Delphic episode expounded in previous section is, of course, the Socratic profession of ignorance, ${ }^{79}$ which provides early Christian authors with ammunition against overtly rationalistic methodology used by their philosophically minded pagan opponents. Lactantius uses the Socratic profession of ignorance backed by oracular response to argue against natural philosophers: ${ }^{80}$

\begin{abstract}
"After him [sc. Pythagoras] Socrates held the first place in philosophy, who was pronounced most wise even by the oracle, because he confessed that he knew one thing only - namely, that he knew nothing. And on the authority of this oracle it was right that the natural philosophers should restrain themselves, lest they should either inquire into those things which they could not know, or should think that they knew things which they did not know." (transl. W. Fletcher)
\end{abstract}

Leaving aside the curious fact that Lactantius here treats the Delphic oracle as trustworthy - pace his fellow apologists introduced in section (3) - Eusebius follows the same line of thought, using Socratic ignorance as an argument against those who indulge themselves in $\phi v \sigma ı \lambda o \gamma$ í $\alpha$, which is perceived to cause atheism: ${ }^{81}$

"So said Socrates, that very man so celebrated by all the Greeks. When, therefore, even this great philosopher had such an opinion of the physiological doctrines of those whom I have mentioned, I think that we too have with good reason deprecated the atheism of them all, since their polytheistic error also seems not to be unconnected with the opinions already mentioned." (transl. E. H. Gifford)

If we return to Lactantius again and consider this section of Divine Institutes, as opposed to the passage from Epitome, where only natural philosophy seems to be discarded, is it clear that the argument is eventually extended to every form of philosophy: "Therefore if nothing can be known, as Socrates taught, or ought to be conjectured, as Zeno taught, philosophy is entirely removed." ${ }^{82}$ Finally, Lactantius conflates otherwise unat-

(by positive means) the existence of sin before the first coming of Christ.

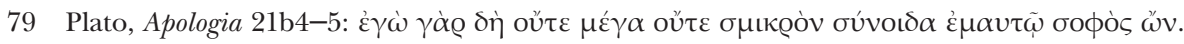

80 Lactantius, Epitome 32.1-2: post hunc [sc. Pythagoram] Socrates philosophiae tenuit principatum sapientissimus etiam oraculo dictus, quia se fatebatur unum scire, quod nihil sciret. cuius oraculi auctoritate apstinere se physicos oportebat, ne aut quaererent ea quae scire non poterant aut scire se putarent quae ignorabant.

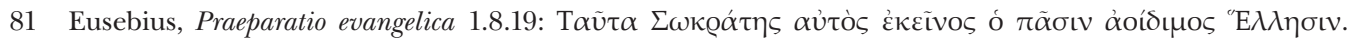

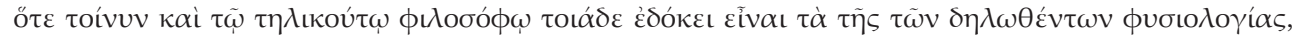

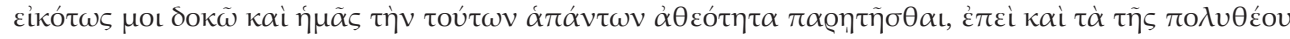

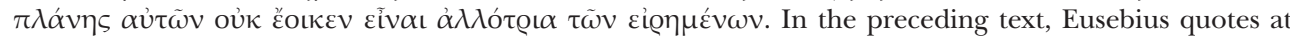
length from Xenophon and Plato.

82 Lactantius, Divinae institutiones 3.4.2: ergo si neque sciri quicquam potest, ut Socrates docuit, neque opinari oportet, ut Zenon, tota philosophia sublata est. 
tested saying quod supra nos, nihil ad $\operatorname{nos}^{83}$ with the peculiar practice of Socratic swearing to produce something very representative of the reception of Socrates in early Christian literature in general: ${ }^{84}$

\begin{abstract}
"Socrates used this well-known proverb: That which is above us is nothing to us. [...] If he wished to overthrow those public superstitions, I do not disapprove of this; yea, I shall rather praise it. [...] But the same man swore by a dog and a goose! Oh buffoon (as Zeno the Epicurean says), senseless, abandoned, desperate man, if he wished to scoff at religion; madman, if he did this seriously, so as to esteem a most base animal as God!" (transl. W. Fletcher)
\end{abstract}

If the object of the dictum is polytheistic religion, Socrates is praised; if the function of the Socratic swearing ${ }^{85}$ is to make fun of any religion (including, presumably, the Christian one), Socrates is surely desperate; and if he means it seriously, he is just plain mad. It may be concluded that the Socratic profession of ignorance is used by early Christian writers to demonstrate the limits of ratiocination unaided by revelation. Since philosophers cannot ascertain the fullness of truth by reason alone, it is necessary to complement (or, rather, supersede) rational investigation by revealed wisdom, which is in turn defended by means of ad hominem epistemic justification through miracles, superior moral behaviour and divine inspiration.

\title{
(5) Conclusion: Omnibus Omnia
}

In his First Letter to Corinthians, Paul the Apostle famously wrote: "To the Jews I became as a Jew, in order to win Jews. To those under the law I became as one under the law (though I myself am not under the law) so that I might win those under the law. To those outside the law I became as one outside the law (though I am not free from God's law but am under Christ's law) so that I might win those outside the law. To the weak I became weak, so that I might win the weak. I have become all things to all people, that

83 Bady (2015: p. 148) connects this formula with negative theology; Bussanich (1999: p. 49) similarly claims that Socratic profession of ignorance amounts to a "rudimentary form of negative theology".

84 Lactantius, Divinae institutiones 3.20.10-15: celebre hoc prouerbium Socrates habuit: quod supra nos, nihil ad nos. [...] quodsi publicas illas religiones uoluit euertere, non inprobo, quin etiam laudabo [...] uerum idem per canem et anserem deierebat. o hominum scurram, ut ait Zeno Epicureus, ineptum perditum desperatum, si cauillari uoluit religionem, dementem, si hoc serio fecit, ut animal turpissimum pro deo haberet!

85 The theme of Socratic swearing is yet another commonplace in the early Christian reception of Socrates. It receives positive evaluation whenever the Christian apologists understand it as a symptom of his rejec-

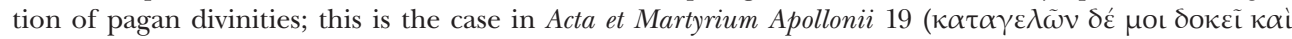

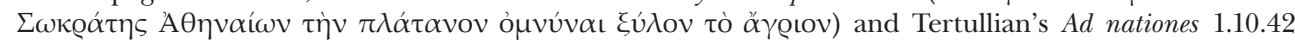
(Socrates in contumeliam eorum quercum et canem et hircum iurat) and Apologeticum 14.7 (Taceo de philosophis, Socrate contentus, qui in contumeliam deorum quercum et hircum et canem deierebat). Socratic swearing receives negative connotation, whenever it is used to demonstrate the folly of pagan religion; see, for instance,

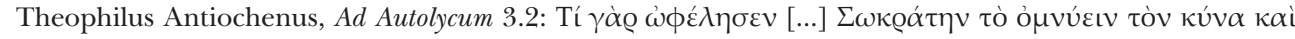

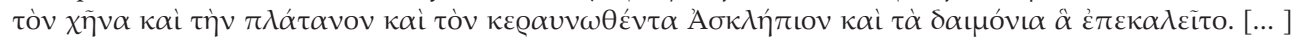

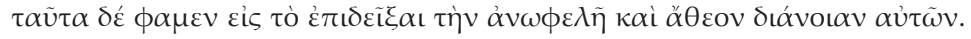


I might by all means save some. I do it all for the sake of the gospel, so that I may share in its blessings." 86 One could reasonably conclude that these words do apply without exception to the reception of Socrates in early Christian literature; the philosopher has indeed become "all things to all people", or at the very least, all things to all the early Christian writers.

The $\delta \alpha \iota$ óviov of Socrates is an evil demon as well as a proof of divine inspiration; his moral character is extolled whenever a parallel with the death of Jesus and the martyrs is needed; his moral character is blemished whenever a contrast with chaste Christians is required; his sentence is accepted as just or unjust according to the immediate rhetorical and argumentative needs of the apologists. One could reasonably ask whether the protean nature of the Socratic figure in early Christianity has any common denominator. With respect to the figure of Socrates, I have demonstrated that any attempts aimed at a reconstruction of a unified conception or interpretation of Socrates in the early Christian writings are destined to fail, let alone in a case where the interpretation is supposed to be a positive one, as many previous scholars thought. ${ }^{87}$ This distorted picture has been largely corrected in more recent studies, ${ }^{88}$ yet the transition from a search for a unified interpretation of Socrates to the purely descriptive catalogue of Sokratesstellen in early Christian literature does not seem to be justified either.

I have tried to show that the early Christian reception of Socrates is not to be seen as a mere haphazard collection of ad hoc claims. I suggest that the unifying element is indeed there, but it does not lie in a single and coherent interpretation of the figure of Socrates, but in the general apologetic needs of the authors. This much has been emphasized in recent studies: For instance, Michael Frede rightly concludes that "ancient Christian remarks about Socrates for the most part follow a rather transparent pattern

861 Corinthians 9, 20-23.

87 Benz (1951: p. 196) provides a typical example of this mistaken view by claiming that early Christian apologists and martyrs provide "ein auffällig einheitliches Bild einer christlichen Auslegung der Gestalt des Sokrates, welche vor allem die Motive des Bildes vom leidenden und sterbenden Gerechten aufgreift". Smith (1990: p. 85) argues that "the most persistent, positive Christian parallel has been that of Jesus and Socrates [...] developed in the earliest apologetic tradition"; Lilla (2006) in an influential encyclopedia of early Christianity concludes that "solo Tertulliano, in coerenca con il suo atteggiamento negativo verso la filosofia greca [...] non si mostra benevolo nei suoi riguardi"; similar position has been advocated already by Jackson (1977: p. 193), who considers Tertullian's negative interpretations of Socrates to be "occasional exceptions". The most recent study of the reception of Socrates in early Christian literature by Henk Bakker focuses solely on the positive interpretations and elegantly relegates all negative assessments of Socrates to a single footnote (Bakker 2015: p. 392, n. 1); Bakker further claims that "in the early ages AD the heroic stature of Socrates was pushed beyond the measure of ordinary man" (op. cit., p. 400).

88 Opelt (1983: p. 198), however with respect to a later period, argues that "im Zeitalter des Kirchenfriedens von einer nur positiven Bewertung des Sokrates zunächst keine Rede sein kann.” Fédou (1998: p. 64) cautiously notes that "même dans le christianisme grec, la grande faveur dont jouit généralement Socrate ne va pas sans quelques reserves ou critiques". Frede (2006: p. 192) concludes that "contrary to a common view, Christians by no means as a rule referred to Socrates in support of their case against the pagans in a positive way". Frede finds this "puzzling" (ibid.), yet there is no reason at all to find it puzzling, since that is precisely what one would expect in early Christian apologetics. Same conclusion is reached by Bady (2014: p. 384), who claims that "Socrate fut doublement récupéré par les auteurs chrétiens: positivement, lorsque son modèle apparaissait conforter le christianisme, ou négativement, lorsque son exemple prouvait l'infériorité du paganisme". 
of argument which is dictated by their apologetic needs, rather than by some deep understanding of the actual Socrates". ${ }^{89}$ This much is certainly true, yet he remains completely silent as to what this "transparent pattern of argument" consists in. The main aim of this study was precisely to show that Socrates might well be all things to all the early Christian writers, but behind most, if not all interpretations of him, there lies a deeper, maybe largely unconscious apologetic aim that is embodied in the defence of the ad hominem model of epistemic justification, vindicating arguments from authority as a legitimate means to establish the truth of Christian beliefs. Simply put, early Christian Socrates is an ad hominem argument in favour of ad hominem argumentation. ${ }^{90}$

\section{Bibliography}

\section{Primary sources}

ANF: Ante-Nicene Fathers. (1867-1873). Ed. A. Roberts, \& J. Donaldson. Edinburgh: T\&T Clark. Apuleius, De philosophia libri. (1991). Ed. C. Moreschini. Berlin: Walter de Gruyter.

Arnobius, Arnobii Adversus nationes libri VII. (1953). Ed. C. Marchesi. Torino - Milano - Padova:

I. B. Paraviae.

Athenagoras, Legatio $\mathcal{E}$ De resurrectione. (1972). Ed. W. R. Schoedel. Oxford: Clarendon Press. Cicero, De natura deorum. (1933). Ed. W. Ax. Leipzig: Teubner.

Clemens Alexandrinus, Stromata. (1960-1970). Ed. L. Früchtel, O. Stählin, \& U. Treu. In Iidem (Eds.), Clemens Alexandrinus (Band 2, 3). Berlin: Akademie Verlag.

Cyprianus, Opera omnia. (1868). Ed. G. Hartel. Wien: Apud C. Geroldi Filium Bibliopolam Academiae.

Diogenes Laertius, Vitae philosophorum. (1964). Ed. H. S. Long. Oxford: Clarendon Press.

Eusebius Caesariensis, Eusebius Werke. Band 8: Die Preparatio evangelica. (1954-1956). Ed. K. Mras. Berlin: Akademie Verlag.

Flavius Josephus, Flavii Iosephi Opera. (1887-1895). Ed. B. Niese. Berlin: Weidmann.

Justinus Martyr, Apologiae pro Christianis. (1994). Ed. M. Marcovich. Berlin - New York: Walter de Gruyter.

89 Frede (2006: p. 201).

90 The ad hominem nature of the arguments incorporating Socrates has been highlighted by several scholars, Edwards (2007: p. 131), speaking about Origen, says that he "has little use for Socrates except now and then as an argumentum ad hominem". Roskam (2010: p. 255) concludes that the authors of early Christian martyrological literature "used obvious similarities between their own situation and the unjust condemnation of the famous Athenian philosophers as an argumentum ad hominem against their pagan judges". Korteweg (2011: p. 148) notes that "there is no reason to assume that Justin's admiration for Socrates went any further than that he used him handily as an argument ad hominem in his apology". All these observations are undoubtedly correct, yet the import of the present study lies in disclosing the fact that Christian apologists not only use Socrates as an argument ad hominem, but, more specifically, as an argument ad hominem in favour of ad hominem argumentation that forms the basis of epistemic justification in early Christianity. 
Justinus Martyr, Dialogus cum Tryphone. (1997). Ed. M. Marcovich. Berlin - New York: Walter de Gruyter.

Lactantius, Opera omnia. (1890). Ed. S. Brandt, \& G. Laubmann. Prague - Wien - Leipzig: Tempsky - Freytag.

Minucius Felix, Octavius. (1982). Ed. B. Kytzler. Stuttgart: Teubner.

Novum Testamentum Graecae. (1993). Ed. E. Nestle, B. Aland, K. Aland, \& al. Stuttgart: Deutsche Bibelgesellschaft.

Origenes, Contre Celse. (1967-1969). Ed. M. Borret. Paris: Éditions du Cerf.

Plato, Platonis opera. (1900-1907). Ed. J. Burnet. Oxford: Clarendon Press.

Pseudo-Clemens Romanus, Die Pseudoklementinen I: Homilien. (1969). Ed. J. Irmscher, F. Paschke, \& B. Rehm. Berlin: Akademie Verlag.

Tertullianus, Opera Catholica. Adversus Marcionem. (1954). Ed. E. Dekkers, \& al. Turnhout: Brepols. Tertullianus, Opera Montanistica. (1954). Ed. A. Gerlo, \& al. Turnhout: Brepols.

The Acts of the Christian Martyrs. (1972). Ed. H. Musurillo. Oxford: Clarendon Press.

The Apostolic Fathers: Greek Texts and English Translations. (2007). Ed. M. W. Holmes. Grand Rapids: Baker Academic.

Theophilus Antiochenus, Ad Autolycum. (1970). Ed. R. M. Grant. Oxford: Clarendon Press.

Xenophon, Xenophontis opera omnia. Vol. II: Memorabilia. (1921). Ed. E. C. Marchant. Oxford: Clarendon Press.

\section{Secondary sources}

Aune, D. E. (1983). Prophecy in Early Christianity and the Ancient Mediterranean World. Grand Rapids: William B. Eerdmans.

Bady, G. (2005). Le Socrate de Platon: Pédéraste ou pédagogue? In L. Basset, \& F. Biville (Eds.), Les jeux et les ruses de l'ambiguïté volontaire dans les textes grecs et latins: Actes de la Table Ronde organisée à la Faculté des Lettres de l'Université Lumière-Lyon 2, 23-24 novembre 2000 (pp. 131-145). Lyon: Maison de l'Orient.

Bady, G. (2014). Socrate entre païens et chrétiens: Procès sans fin ou héritage commun? Revue des études grecques, 127(2), 377-395.

Bady, G. (2015). «Saint Socrate»? L'«atopie» du philosophe chez les Pères de l'Église. In É. Ayroulet (Ed.), «Les Pères de l'Église»: Première rencontre entre foi et raison (pp. 95-166). Lyon: Profac-Théo.

Bakker, H. A. (2015). Beyond the Measure of Man: About the Mystery of Socratic Martyrdom. Church History and Religious Culture, 95, 391-407.

Barnes, J. (1997). Raison et foi: Critique païenne et réponses chrétiennes. Annuaire de la Société Suisse de Philosophie (Studia Philosophica), 56, 183-209.

Benz, E. (1950). Der gekreuzigte Gerechte bei Plato, im Neuen Testament und in der alten Kirche. Mainz: Verlag der Akademie der Wissenschaften und der Literatur.

Benz, E. (1951). Christus und Sokrates in der alten Kirche: Ein Beitrag zum altkirchlichen Verständnis des Märtyrers und des Martyriums. Zeitschrift für die Neutestamentliche Wissenschaft und die Kunde der Älteren Kirche, 43(1), 195-224. 
Bochet, I. (2008). Transcendence divine et paradoxe de la foi chrétienne: La polémique de Tertullien contre Marcion. Recherches de Science Religieuse, 96(2), 255-274.

Bostick, A. P. (1935). A Comparison of the Portrait of Jesus in Gospels with the Portrait of Socrates in the Writings of Plato and Xenophon. Journal of the National Association of Biblical Instructors, 3(2), 94-101.

Boyarin, D. (1999). Dying for God: Martyrdom and the Making of Christianity and Judaism. Stanford: Stanford University Press.

Bowersock, G. W. (1995). Martyrdom and Rome. Cambridge: Cambridge University Press.

Brancacci, A. (2001). Le Socrate de Dion Chrysostome. In A. Laks, \& M. Narcy (Eds.), Philosophie antique 1: Figures de Socrate (pp. 167-182). Villeneuve d'Ascq: Presses Universitaires du Septentrion.

Brickhouse, T. C., \& Smith, N. D. (1994). Plato's Socrates. New York - Oxford: Oxford University Press.

Brickhouse, T. C., \& Smith, N. D. (2002). The Trial and Execution of Socrates: Sources and Controversies. New York - Oxford: Oxford University Press.

Bussanich, J. (1999). Socrates the Mystic. In J. J. Cleary (Ed.), Traditions of Platonism: Essays in Honour of John Dillon (pp. 29-51). Aldershot: Ashgate.

Carlson, M. L. (1948). Pagan Examples of Fortitude in the Latin Christian Apologists. Classical Philology, 43(2), 93-104.

Cobb, L. S. (2014). Polycarp's Cup: Imitatio in the Martyrdom of Polycarp. Journal of Religious History, 38(2), 224-240.

Dassmann, E. (1993). Christus und Sokrates: Zu Philosophie und Theologie bei den Kirchenvätern. Jahrbuch für Antike und Christentum, 36, 33-45.

Destrée, P., \& Smith, N. D. (Eds.). (2005). Socrates' Divine Sign: Religion, Practice, and Value in Socratic Philosophy. Kelowna: Academic Printing and Publishing [reprint of a special issue of the journal Apeiron, 38(2)].

Detienne, M. (1967). Les Maîtres de vérité dans la Grèce archaïque. Paris: François Maspero.

Döring, K. (1999). Sokrates im Urteil der frühen Christen. In H. Kessler (Ed.), Sokrates-Studien IV: Das Lächeln des Sokrates (pp. 47-70). Zug: Die Graue Edition.

Dorion, L.-A. (2011). The Rise and Fall of the Socratic Problem. In D. R. Morrison (Ed.), The Cambridge Companion to Socrates (pp. 1-23). Cambridge: Cambridge University Press.

Droge, A., \& Tabor, J. (1992). A Noble Death: Suicide $\mathcal{E}$ Martyrdom among Christians and Jews in Antiquity. San Francisco: Harper.

Edwards, M. (2007). Socrates and the Early Church. In M. B. Trapp (Ed.), Socrates from Antiquity to the Enlightenment (pp. 127-141). Aldershot: Ashgate.

Erler, M. (2001). Sokrates' Rolle im Hellenismus. In H. Kessler (Ed.), Sokrates-Studien V: Sokrates, Nachfolge und Eigenwege (pp. 201-232). Zug: Die Graue Edition.

Fédou, M. (1998). La figure de Socrate selon Justin. In B. Pouderon, \& J. Doré (Eds.), Les apologistes chrétiens et la culture grecque (pp. 51-66). Paris: Beauchesne.

Frede, M. (2006). The Early Christian Reception of Socrates. In L. Judson, \& V. Karasmanis (Eds.), Remembering Socrates: Philosophical Essays (pp. 188-202). Oxford: Clarendon Press.

Frend, W. H. C. (2008). Martyrdom and Persecution in the Early Church: A Study of a Conflict from the Maccabees to Donatus. Cambridge: James Clarke \& Co. [corrected edition of the 1965 original]. 
Giannantoni, G. (2001). Les perspectives de la recherche sur Socrate. In G. Romeyer Dherbey, \& J.-B. Gourinat (Eds.), Socrate et les Socratiques (pp. 1-19). Paris: Librairie Philosophique J. Vrin.

Gigon, O. (1947). Sokrates: Sein Bild in Dichtung und Geschichte. Bern: Francke.

Guerra, A. J. (1991). Polemical Christianity: Tertullian's Search for Certitude. The Second Century: A Journal of Early Christian Studies, 8, 109-123.

Hanfmann, G. M. A. (1951). Socrates and Christ. Harvard Studies in Classical Philology, 60, 205-233. Heidegger, M. (1969). Zur Sache des Denkens. Tübingen: Max Niemeyer.

Heidegger, M. (2006). Sein und Zeit. Tübingen: Max Niemeyer.

Jackson, D. (1977). Socrates and Christianity. Classical Folia, 31(2), 189-206.

Jedrkiewicz, S. (2011). Sign, Logos, and Meaning: The Platonic Socrates and His Daemonic Experience. Mètis (n.s.), 9, 209-243.

Kitzler, P. (2015). From Passio Perpetuae to Acta Perpetuae: Recontextualizing a Martyr Story in the Literature of the Early Church. Berlin - Boston: Walter de Gruyter.

Kloppenborg, J. S. (1992). Exitus Clari Viri: The Death of Jesus in Luke. Toronto Journal of Theology, 8(1), 106-120.

Kollmann, B. (2011). Neutestamentliche Wundergeschichte. Stuttgart: Kohlhammer.

Korteweg, T. (2011). Justin Martyr and His Demon-Ridden Universe. In N. Vos, \& W. Otten (Eds.), Demons and the Devil in Ancient and Medieval Christianity (pp. 145-158). Leiden - Boston: Brill.

Labhardt, A. (1950). Tertullien et la philosophie ou la recherché d'une «position pure». Museum Helveticum, 7(3), 159-180.

Lapatin, K. (2006). Picturing Socrates. In S. Ahbel-Rappe, \& R. Kamtekar (Eds.), A Companion to Socrates (pp. 110-155). Malden - Oxford: Blackwell Publishing.

Larmer, R. A. (2011). The Meanings of Miracle. In G. H. Twelftree (Ed.), The Cambridge Companion to Miracles (pp. 36-53). Cambridge: Cambridge University Press.

Lilla, S. (2014). Socrate. In A. di Bernardino (Ed.), Nuovo dizionario patristico e di antichità cristiane (pp. 5037-5038). Genova - Milano: Casa Editrice Marietti.

Long, A. (1988). Socrates in Hellenistic Philosophy. Classical Quarterly, 38, 150-171.

MacMullen, R. (1984). Christianizing the Roman Empire (A.D. 100-400). New Haven - London: Yale University Press.

MacMullen, R. (1981). Paganism in the Roman Empire. New Haven - London: Yale University Press.

McPherran, M. (1996). The Religion of Socrates. Pennsylvania: The Pennsylvania State University Press.

Melissoni, G. (1930). Socrate nella tradizione cristiana dei primi secoli. Didaskaleion, 9(3), 125-176.

Middleton, P. (2006). Radical Martyrdom and Cosmic Conflict in Early Christianity. London - New York: T\&T Clark.

Montuori, M. (1992). The Socratic Problem: The History - The Solutions. Amsterdam: J. C. Gieben.

Moss, C. R. (2010). The Other Christs: Imitating Jesus in Ancient Christian Ideologies of Martyrdom. Oxford: Oxford University Press.

Moss, C. R. (2012). Ancient Christian Martyrdom: Diverse Practices, Theologies, and Traditions. New Haven - London: Yale University Press.

Müller, K. W. (1986). Schierlingstrank und Kreuzestod: Anmerkungen zu den Prozessen gegen Sokrates und Jesus. Antike und Abendland, 32, 66-88. 
Nietzsche, F. (1999). Kritische Studienausgabe (Ed. M. Montinari, \& G. Colli). München - Berlin New York: Deutscher Taschenbuch Verlag - Walter De Gruyter.

Opelt, I. (1983). Das Bild des Sokrates in der christlichen lateinischen Literatur. In H.-D. Blume, \& F. Mann (Eds.), Platonismus und Christentum: Festschrift für Heinrich Dörrie (pp. 192-207). Münster: Aschendorff.

Patzer, A. (1987). Der historische Sokrates. Darmstadt: Wissenschaftliche Buchgesellschaft.

Prolović, J. (2011). Socrates and St. John the Apostle: The Interchangeable Similarity of Their Portraits. ЗОГРАФ, 35, 1-20.

Reeve, C. D. C. (1989). Socrates in the Apology: An Essay on Plato's Apology of Socrates. Indianapolis Cambridge: Hackett Publishing Company.

Ritter, A. M. (1998). Sokrates und Christus: Ein Brief an Herwig Görgemanns. In: M. Baumbach, H. Köhler, \& A. M. Ritter (Eds.), Mousopolos Stephanos: Festschrift für Herwig Görgemanns (pp. 8-19). Heidelberg: Universitätsverlag C. Winter.

Rivas, E. G. (2003). El martirio del filósofo: Sócrates en los escritos de San Justino mártir. Cuadernos de Teología, 22, 279-294.

Roskam, G. (2010). The Figure of Socrates in the Early Christian Acta Martyrum. In J. Leemans (Ed.), Martyrdom and Persecution in Late Antique Christianity: Festschrift Boudewijn Dehandschutter (pp. 241-256). Leuven: Peeters.

Sandnes, K. O. (1993). Paul and Socrates: The Aim of Paul's Areopagus Speech. Journal for the Study of the New Testament, 50, 13-26.

Saudelli, L. (2014). «Dieu» ou «démon» de Socrate? Augustine contre Apulée. Revue d'études augustiniennes et patristiques, 60, 67-90.

Sissa, G. (2012). Socrates' Passion. In J. N. Bremmer, \& M. Formisano (Eds.), Pepetua's Passions: Multidisciplinary Approaches to the Passio Perpetuae et Felicitatis (pp. 244-253). Oxford: Oxford University Press.

Skarsaune, O. (1987). The Proof from Prophecy: A Study in Justin Martyr's Proof-Text Tradition, Text Type, Provenance, Theological Profile. Leiden: Brill.

Skarsaune, O. (1996). Judaism and Hellenism in Justin Martyr, Elucidated from His Portrait of Socrates. In H. Cancik, H. Lichtenberger, \& P. Schäfer (Eds.), Geschichte - Tradition - Reflexion: Festschrift für Martin Hengel zum 70. Geburtstag, Band III, Frühes Christentum (pp. 585-611). Tübingen: J. C. B. Mohr (Paul Siebeck).

Smith, J. Z. (1990). Drudgery Divine: On the Comparison of Early Christianities and the Religions of Late Antiquity. Chicago: The University of Chicago Press.

Stavru, A. (2013). The Present State of Socratic Studies: An Overview. In F. de Luise, \& A. Stavru (Eds.), Socratica III: Studies on Socrates, the Socratics, and the Ancient Socratic Literature (pp. 11-26). Sankt Augustin: Academia Verlag.

Stegemann, E. W. (1999). Paulus, Sokrates und Seneca: Zu den Anfängen christlicher Literaturund Philosophiegeschichte. In R. Faber, \& B. Naumann (Eds.), Literarische Philosophie - philosophische Literatur (pp. 77-93). Würzburg: Königshausen \& Neumann.

Sterling, G. (2001). Mors philosophi: The Death of Jesus in Luke. Harvard Theological Review, 94(4), 383-402.

Strecker, G. (1992). The Pseudo-Clementines: Introduction. In W. Schneemelcher (Ed.), New 
Testament Apocrypha, Volume II: Writings Related to the Apostles, Apocalypses and Related Subjects (pp. 483-492). Cambridge: James Clarke \& Co.

Stróżyński, M. (2014). Old Age before the Court: Monnica and Socrates in Book Nine of Augustine's Confessions. Symbolae Philologorum Posnaniensium Graecae et Latinae, 24(2), 119-134.

Tabb, B. J. (2015). Is the Lukan Jesus a "Martyr"? A Critical Assessment of a Scholarly Consensus. The Catholic Biblical Quarterly, 77, 280-301.

Urbanová, D. (2014). Latinské proklínaci tabulky na územi řimského impéria. Brno: Host - Masarykova univerzita.

Van Henten, J. W. (2012). Noble Death and Martyrdom in Antiquity. In S. Fuhrmann, \& R. Grundmann (Eds.), Martyriumsvorstellungen in Antike und Mittelalter: Leben oder sterben für Gott? (pp. 85-110). Leiden - Boston: Brill.

Van Henten, J. W. - Avemarie, F. (2002). Martyrdom and Noble Death: Selected Texts from GraecoRoman, Jewish and Christian Antiquity. London: Routledge.

Vlastos, G. (1991). Socrates: Ironist and Moral Philosopher. Ithaca: Cornell University Press.

Waterfield, R. (2013). The Quest for the Historical Socrates. In J. Bussanich, \& N. D. Smith (Eds.), The Bloomsbury Companion to Socrates (pp. 1-19). London - New York: Bloomsbury Academic.

Young, M. O. (1989). Justin, Socrates and the Middle-Platonists. Studia Patristica, 18(2), 161-166.

Zaidman, L. B. (2013). Xénophon, l'oracle de Delphes et la divination. Kernos, 26, 59-72.

Zanker, P. (1995). Die Maske des Sokrates: Das Bild des Intellektuellen in der antiken Kunst. München: C. H. Beck.

Juraj Franek, Ph.D. / j.franek@mail.muni.cz

Department of Classical Studies

Masaryk University, Faculty of Arts

Arna Nováka 1, CZ-602 00 Brno, Czech Republic 